\title{
1. The criminal reconciliation (xingshi hejie) system in China: background, pilot projects and debates*
}

In August 2011, the People's Republic of China (China) launched the second major revision of its Criminal Procedure Law (CPL) after its first major revision in 1996. In the revision draft, which was later passed in the fifth meeting of the 11th National People's Congress in March 2012, Articles 277 to 279 provide a statutory basis for a new 'special procedure,' which allows the alleged victims and suspects/defendants of certain crimes to 'reconcile' (hejie) and thereby close criminal cases. This revised CPL has been in effect since 1 January 2013.

Article 277 stipulates the 'requirements' and 'scope' of cases eligible for this process. It may (but does not have to) be initiated in the case of a suspected crime under Chapters 4 and 5 of the Criminal Law ${ }^{1}$ if the crime has 'arisen' from what is characterized as 'disputes among the people' (minjian jiufen) which could lead to sentences of no more than three years' imprisonment, and in the case of a negligent 'crime' with a potential sentence of no more than seven years' imprisonment. ${ }^{2}$ In addition, in these cases, the suspect/defendant should have 'regretted sincerely' and 'obtained the victim's forgiveness through compensation, apology, and other methods'; the law also requires that mediation must be initiated on the basis of the victim's (not both parties') voluntariness. ${ }^{3}$

* Some sections of this chapter and Chapters 4 to 5 were accepted for publishing in a forthcoming issue of the Journal of Comparative Law as an article entitled 'Buying "Leniency," Selling "Justice"? A Critical Discussion of "Criminal Reconciliation" (xingshi hejie) under China’s Revised Criminal Procedural Law.'

1 Chapter 4 of the PRC Criminal Law is about 'crimes infringing upon citizens' rights of the person and democratic rights'; Chapter 5 is about 'crimes of property violation.'

2 There is an exception for 'malfeasance crimes'; and suspects/defendants who committed an intentional crime within five years prior to the case at hand are excluded from this process.

3 Ibid. 
Article 278 articulates the public authorities' role in this process: the Public Security Bureau, the People's Procuratorate or the People's Court should hear the parties' and other relevant people's opinions, review the reconciliation with regard to its voluntary nature and compliance with the law, and produce reconciliation agreements. ${ }^{4}$

Article 279 is about the outcomes of this process. It provides that the police may make suggestions for a lenient disposition to the People's Procuratorate; the prosecutor may also make such suggestions to the People's Court or decide not to prosecute; and the judge may give a lenient sentence to the defendant according to the law following a successful criminal reconciliation process. ${ }^{5}$

Overall, this revision means that reconciliation, which under the 1996 CPL could only be used in 'private prosecution (zisu) cases' ${ }^{6}$ and 'civil litigation collateral to criminal proceedings (xingshi fudai minshi susong), ${ }^{7}$ is now legally allowed in certain public prosecution cases.

Having a legal basis only since then, such a procedure, generally called 'criminal reconciliation' (xingshi hejie) and referred to as a 'procedure for voluntary reconciliation among the parties in public prosecution cases,' had been widely used by the Public Security Bureau, the People's Procuratorate and the People's Court nearly nationwide in China as 'pilot projects' from the beginning of the 2000s.

4 Article 278 CPL.

5 Article 279 CPL.

6 'Private prosecution (zisu) cases,' according to Article 170 of the 1996 CPL and Article 204 of the 2012 CPL, refers to cases 'to be handled only upon complaint,' cases 'for which the victims have evidence to prove that those are minor criminal cases' and 'cases for which the victims have evidence to prove that the defendants should be investigated for criminal responsibility according to law because their acts have infringed upon the victims' personal or property rights, whereas, the public security organs or the People's Procuratorates do not investigate the criminal responsibility of the accused.' According to Article 172 of the 1996 CPL and Article 206 of the 2012 CPL, 'the People's Court may conduct mediation in a case of private prosecution.' See the English translation of the $1996 \mathrm{CPL}$ at http://www.cecc.gov/pages/newLaws/criminalProcedureENG. php (last accessed on 20 March 2011).

7 According to Article 77 of the 1996 CPL and Article 99 of the 2012 CPL, 'if a victim has suffered material losses as a result of the defendant's criminal act, he/she shall have the right to file an incidental civil action during the course of the criminal proceeding.' Article 96 of the Judicial Interpretation on CPL issued by the Supreme People's Court [最高人民法院关于执行《中华 人民共和国刑事诉讼法》若干问题的解释] in 1998 further provides that 'the People's Court can conduct mediation in the civil litigation collateral to criminal proceedings, except for those cases lodged by the People's Procuratorate.' 
The first section of this chapter provides a background of the introduction of criminal reconciliation in China, which is mainly a result of the authorities' changing perspectives on legal reform as well as on the criminal justice system in the early 2000s. Dating back to the late 1970s, after the revolutionary Mao era and the chaotic Cultural Revolution ended, China's legal reforms could largely be understood as taking the direction aimed at entrenching 'the rule of law' conceived in liberal terms. By contrast, since the early 2000s, the Chinese authorities began to emphasize concepts such as 'people's judiciary,' 'harmonious judiciary' and 'big mediation (da tiaojie), dozens of which were actually adopted in the Mao era, under the 'ultimate goal' of 'establishing a harmonious society.' Designed as a process mainly based on the parties' (namely, the victim and the suspect/defendant) voluntary reconciliation, criminal reconciliation has been officially valued as overcoming the shortcomings of the normal criminal procedure, which is set as an adversarial system in the 1996 CPL, thereby bringing about the effects of 'satisfying the parties,' 'bringing "closure" (an jie shi liao) to criminal cases' and 'preventing petitioning related to judicial cases (she $\mathrm{fa}$ shangfang), a phenomenon denounced by the authorities as a manifestation of 'disharmony' and 'instability.' ${ }^{\prime}$ And, as stated by the Chinese authorities, such an explosion of petitioning is the judicial system's failure in fulfilling its political tasks, which significantly include maintaining social stability and harmony. ${ }^{9}$

8 'Petitioning' (shangfang or xinfang) is a system established in the 1950s in China by which a citizen, legal person or any other organization reports facts, submits suggestions or files complaints to the Xinfang (literally: 'Letters' and 'Visits') offices, which are established at all levels of administration and in all branches of the Party and State. 'Petitioning related to judicial cases' (she fa shangfang or she su shangfang) in a broad sense refers to the petitioning that concerns cases handled by the People's Courts, the People's Procuratorates and the Public Security Bureaus. In a narrow sense, it only refers to petitioning concerning cases handled by the People's Courts (in some instances, what petitioners complain about is inaction on the part of these authorities, i.e. they complain that a case has not been handled properly). See: Carl F. Minzner 'Xinfang: An Alternative to Formal Chinese Legal Institutions' (2006) Vol. 42 Stanford Journal of International Law; Li Yinfang [李银芳] Li Jinfu [李金富] 'Reasons and Strategies of Petitioning Related to Judicial Cases [涉法上访案件的成因及对策]' at http://www.dffy.com/fayanguancha/sh/2004 09/20040916085512.htm (last accessed on 8 February 2012).

9 Wu Aiying [吴爱英] 'Sparing No Effort to Make Judicial Organs Maintain Social Stability [全力做好司法行政机关维护社会稳定工作] at 
This change of perspectives has triggered much debate and criticism in academia domestically and abroad - in general, one group of scholars appreciates this shift as the authorities' careful adjustment of the judicial system towards 'Chinese characteristics and Chinese people's real needs.' According to them, mediation, or reconciliation, embeds China's traditional culture, which is still prevailing today, whereas liberal reforms of the judiciary and litigation, which are 'transplanted from western jurisdictions,' are not feasible in China. To them, the legal reform in the direction of the rule of law is the root of the upsurge of petitioning to government since the early 2000s. Meanwhile, some liberal-minded scholars, questioning the assertion of the prevalence and preference of mediation in China today, criticize this shift as an obvious retrogression of the Chinese judiciary, in particular in terms of judicial independence and judicial professionalism. Through discussing the resemblance of the current judicial reform with the judiciary in the Mao era, they argue that this shift has demonstrated the ruling Party (i.e. the Communist Party of China)'s intensifying and authoritarian control of the judiciary when it faces increasing crises and threats to its rule from society.

A comprehensive examination of criminal reconciliation, a major programme introduced against such a background, can shed some light on the current legal reform as well as the debates over it. The second section of this chapter provides a historical review of the Chinese mediation systems that have been in place since the Mao era, connecting mediation to the official design as well as practices of criminal reconciliation. The critical review shows that the mediation system in China is always connected closely with the Party's policies and is a tool of the Party to serve its political goals, such as suppressing disputes, instead of empowering the parties in resolving disputes. Such a programme can seriously infringe upon the parties' rights and voluntariness. The problems with the Chinese mediation systems raise doubts and concerns over criminal reconciliation regarding its real influences and ends.

The final section of this chapter critically overviews the existing discussions over criminal reconciliation practices. A literature review shows that the positive appraisals mainly focus on its effectiveness of smoothing compensation, satisfying the parties, educating the perpetrators, and thereby bringing 'closure' to disputes. And the criticisms surround the problems of unfairness (to economically weak suspects/ defendants), coercion by public power, and violations of the current legal

http://www.gov.cn/gzdt/2012-10/23/content_2249495.htm (last accessed on 9 July 2015). 
regulations governing this programme. Despite the plausibility of critical arguments, there are essential deficiencies with the existing literature discussing criminal reconciliation. For one thing, most of the appraisals are based on 'second-hand information,' some of which are even directly derived from official websites; for another, since the authors producing most of the empirical studies are usually officials implementing this programme themselves or scholars cooperating with these officials, the credibility of the empirical assessment is suspect. In this sense, information on the actual functioning of criminal reconciliation is of great significance in examining whether or not, or to what extent, the interaction between public power and individuals in this process resembles that in mediation since the Mao era, and importantly, whether this programme is helpful to promote a 'harmonious society' or doing harm to rights and justice. The author's empirical study discussed in the ensuing chapters responds to these concerns critically.

\subsection{LEGAL REFORMS IN CHINA: FROM BUILDING THE RULE OF LAW SYSTEM TO ESTABLISHING A HARMONIOUS SOCIETY}

An account of the introduction of 'criminal reconciliation' in China must first address the concept of 'harmonious society' (hexie shehui), a political goal embedded in the ideology of this process.

This political goal was formulated when the Party found that there had been increasing 'social unrest' ('unrest' in the Party-state's definition) in China since the early 21 st century. The 'Central Commission of Comprehensive Governing' (zhongyangzonghe zhili bangongshi) stated that 'currently, China is at the very point of social and economic transition, so contradictions among the people (renmin neibu maodun) $)^{10}$ are sharp,

10 'Contradictions among the people (renmin neibu maodun)' was a concept initially advanced by Mao Zedong in 'On the Correct Handling of Contradictions among the People' in 1957. In this article, conflicts in society were categorized into two different types - 'contradictions among the people (renmin neibu maodun)' and 'contradictions between the people and the enemies (di wo maodun), which, according to Michael Palmer, also resembled the distinction made by Lenin as 'antagonistic contradictions' (duikangxing maodun) and 'nonantagonistic contradictions' (fei duikangxing maodun). Such a distinction was mainly for mobilizing people in class struggle. Contradictions among the people are 'the everyday disputes between people that arise in the course of work, 
criminal offences are frequent, and fights against enemies ${ }^{11}$ are complicated.' ${ }^{2}$ Consequently, in 2004, the Party formally announced a policy of 'establishing a socialist harmonious society' at the fourth plenary session of the 16th Central Committee of the Chinese Communist Party (CCP). According to the 'Decision' published after this meeting, there were six main requirements or features of 'socialist harmonious society.' They were 'democracy and rule of law' (minzhu fazhi), 'fairness and justice' (gongping zhengyi), 'integrity and friendship' (chengxin you'ai), 'stability and order' (anding youxu), 'great dynamism' (chongman huoli) and 'men living in harmony with nature' (ren yu ziran hexie xiangchu). ${ }^{13}$ Apparently, the first two requirements ('democracy and the rule of law' and 'fairness and justice') were directly targeting the legal system.

Announcing the establishment of a 'socialist harmonious society', the Party seemed to follow its political discourse in the 1990s of establishing 'socialist rule of law' - for instance, as noted by Leïla Choukroune and Antoine Garapon, the Party stressed that 'a harmonious society is a society governed by law'; 'a harmonious society depends on the rule of law'; 'a harmonious society needs a stronger legal system that wields

production, and domestic life.' 'Contradictions among the people' are 'nonantagonistic' so they are best handled through non-coercive ways such as mediation. See: Michael Palmer 'The Revival of Mediation in the People's Republic of China: (1) Extra-judicial Mediation' in W.E. Butler (ed) Yearbook on Socialist Legal Systems New York, Transnational Publishers 1987, 227-8.

11 According to Mao Zedong's expression in 'On the Correct Handling of Contradictions among the People' in 1957, the 'contradictions between the enemy and the people are antagonistic contradictions.' See: the English translation of this work at http://www.peopleofcolororganize.com/wp-content/uploads/ pdf/poco/contradictions.pdf (last accessed on 9 July 2015). Enemies are mainly 'former exploiting classes and counterrevolutionaries' and conflicts between the enemy and the people should be handled through coercive methods, including 'punishment according to law.' See: Stanley Lubman 'Mao and Mediation: Politics and Dispute Resolution in Communist China' (1967) Vol. 55 No 5 California Law Review 1302; Fu Hualing 'Access to Justice in China: Potentials, Limits, and Alternatives' (draft) at http://papers.ssrn.com/sol3/papers.cfm? abstract_id=1474073 (last accessed on 9 July 2015).

12 The Central Commission of Comprehensive Governing [中央社会治安综合治理委员会办公室] (ed) Strategies for the Long-term Peace and Stability [ 长治久安之策] Beijing, Chang'an Press [中国长安出版社] 2009, 295.

13 See relevant reports on Xinhua Net at http://news.xinhuanet.com/politics/ 2006-08/09/content_4939383.htm (last accessed on 4 January 2011). 
greater authority.' ${ }^{14}$ However, if looking further into judicial documentation and practices under this political blueprint of a 'harmonious society,' a patent and essential shift can be spotted - reforms in the Chinese judiciary under the policy of 'promoting a socialist harmonious society,' ranging from guidelines to practices, have shown that mediation and reconciliation have been recognized by the authorities as the most effective way to address perceived 'factors of instability' in the judicial process, such as petitioning, appeals and protests by dissatisfied parties to a legal dispute.

As widely acknowledged, Mao Zedong's death and the end of the chaotically lawless ten-year Cultural Revolution in 1976 ushered in a new era of limited liberalization in China. ${ }^{15}$ The leadership of Deng Xiaoping, announcing that 'the principal contradiction in China today is no longer class struggle but between the growing material and cultural needs of the people and the backwardness of social production,' started to construct a steady and formal legal system in an attempt to create a 'stable and orderly' domestic environment as well as to earn international cooperation for China's economic developments. ${ }^{16}$ The following nearly three decades have witnessed long strides by the legal system - China has built a formal legal framework composed of abundant legislation, including those conceiving individual rights in liberal terms and constraints of state behaviours. ${ }^{17}$ The Party-state also devoted enormous resources to legal education and professional training. ${ }^{18}$ Legal professionalism has since gained substantial developments - the number of judges, prosecutors, lawyers and law schools have amounted evidently; professionals with formal legal training have gradually filled in the legal system and replaced revolutionary cadres. ${ }^{19}$ So does legal formalism - adjudication according to law, rather than mediation, has been emphasized by

14 Leilla Choukroune, Antoine Garapon 'The Norms of Chinese Harmony' (2007) 3 China Perspectives 37.

15 Leng Shao-chuan, Chiu Hungdah, Criminal Justice in Post-Mao China: Analysis and Documents Albany, State University of New York Press 1985, 35.

16 Randall Peerenboom, China's Long March Toward Rule of Law Cambridge, Cambridge University Press 2002, 55; supra note 15, 35-6.

17 Supra note 15.

18 Jerome A. Cohen 'China's Legal Reform at the Crossroads' at http:// www.cfr.org/china/chinas-legal-reform-crossroads/p10063 (last accessed on 17 May 2015).

19 Fu Hualing, Richard Gullen 'From Mediatory to Adjudicatory Justice: The Limits of Civil Justice Reform in China' in Margaret Y.K. Woo and Mary E. Gallagher (eds) Chinese Justice: Civil Dispute Revolution in China Cambridge, Cambridge University Press 2011, 30. 
the authorities as the priority of the judicial system in addressing disputes. ${ }^{20}$ Judicial reforms launched in the late 1990s embodied clearer intentions of advancing procedural fairness and justice. ${ }^{21}$ Even in the conduct of mediation, legitimacy has been officially stressed, which is, as set in laws, tested based on voluntariness and lawfulness. ${ }^{22}$ A domestic leading law professor Guo Daohui summarized that in the past three decades there were three prominent landmarks in China's path towards the rule of law:23

The first one is the Party's third plenary session of the eleventh central committee held in 1978, which launched the policy and principle that 'there must be laws to go by (you fa ke yi), the laws must be observed and strictly enforced (you fa bi yi, zhifa bi yan), and law-breakers must be held accountable (weifa bi jiu)' - it is the sign of terminating the lawlessness in the Cultural Revolution and starting to build a 'rule by law' system. The second landmark is the promulgation of 'ruling the country according to law (yi fa zhiguo) and building a socialist rule by law country' in 1997 - since then, rule by law became the Party's political basic line, and debates over 'rule by law' and 'rule of law' had been expanding and flourishing. The third breakthrough happened in 1999, when for the first time the concept of 'rule of law' was entrenched in the Constitution. The Party stated that 'the premise of rule of law is ruling in accordance with the Constitution, and the premise of governing in accordance with law is governing in accordance with the Constitution.'

Yet in 2004, the year when 'harmonious society' was underscored by the Party as its central policy, mediation was expressly re-emphasized in the Chinese judicial system. In that year, the Supreme People's Court (SPC) promulgated 'Provisions on Several Issues Concerning the Civil Mediation Work of the People's Court.' In explaining the background and function of these 'Provisions,' Huang Songyou, the then vice-president of the SPC, said: ${ }^{24}$

20 Ibid.

21 Supra note $19,39$.

22 Supra note 19, 38.

23 Jiang Ping [江平] Guo Daohui [郭道晖] Li Buyun [李步云] 'Review: Further Discussions on Rule of Law and Rule of Man [温故: 再谈 法治与人治大讨论]' at http://www.aisixiang.com/data/80806.html (last accessed on 3 November 2011).

24 'Huang Songyou Answered Journalists Questions Regarding "Provisions of the Supreme People's Court about Several Issues Concerning the Civil Mediation Work of the People's Court" [黄松有就《关于人民法院民事调解 
Mediation (in litigation) is a significant means of the People's Court to enforce judicial authority and has its unique advantages in resolving disputes. It was called 'oriental experience' by the international jurisdiction. However, in recent years, some courts have over-emphasized 'announcing verdicts in court hearings,' and failed with paying sufficient attention to mediation. They did not mediate when they should or they can [mediate], which has resulted in the reduction of mediation rate and rising of appealing rate. The pressure of petition has been augmenting as well.

Mediation (in litigation) has four main advantages: first, it makes litigation more 'humanized' (renxing hua). Since it resolves disputes through the parties' voluntary negotiation, rather than the judge's adjudication, the parties can understand and accept it more easily. Second, mediation highlights friendly negotiation and compromise and facilitates the parties' mutual understanding and cooperation, which can largely weaken the antagonism between the two parties and thereby promotes social harmony and stability. Third, mediation is more flexible and efficient, so it can not only alleviate the parties' burden but also save judicial resources. The fourth and also the most important advantage is that, resolving a case through mediation meets the substantial requirement of judicial fairness. Only the result opted by the parties themselves can mostly meet their needs and interests, which is the substantial justice the parties pursue. So it can facilitate the parties' fulfilment [of the agreement reached in mediation] on their initiatives.

Afterwards, in 2005, by announcing the principle of 'fusing trials and mediation, bringing "closure" (tiao pan jiehe, an jie shi liao), the SPC stressed that both mediation and adjudication were means of the courts to address disputes, and should serve a common end of reducing social contradiction and promoting social harmony to the furthest extent. ${ }^{25}$ Yet we can observe that until then, although mediation gained the central judicial authorities' promotion, it was not prioritized over adjudication. Some commented that at that time the SPC had not 'given up on the direction of judicial reforms towards formal adjudication and procedural justice.' 26 Nevertheless, in February 2009, the SPC explicitly changed

工作若干问题的规定》答记者问]' at http://www.china.com.cn/chinese/PI-c/ 661957.htm (last accessed on 12 May 2015).

25 In Chinese, “能调则调, 当判则判, 调判结合, 案结事了. See: Xinhua News Agency 'Mediate When It Can, Adjudicate When It Should, Fuse Trials and Mediation, Bring Closure [新华社] “能调则调, 当判则判, 调判结合, 案结事了]' at http://www.gov.cn/2007lh/content_549985.htm (last accessed on 3 November 2011)

$26 \mathrm{Wu}$ Yingzi [吴英姿] “"Mediation First”: Reform Pattern and Legal Interpretation [“调解优先”: 改革范式与法律解读]' at http://article.chinalaw info.com/ArticleHtml/Article_78723.shtml (last accessed on 20 June 2015). 
this principle to 'prioritizing mediation, fusing trials and mediation (tiaojie youxian, tiao pan jiehe), and started to promote mediation at all the stages of processing a case as well as in all kinds of cases including criminal and administrative litigation. ${ }^{27}$ The judicial system in which mediation plays a dominant role aimed at addressing contradictions is officially called 'harmonious judiciary' (hexie sifa). ${ }^{28}$

Actually, in the criminal justice system, mediation had been promoted several years earlier. In 2006, in order to provide, as it were, a more detailed 'guide' to the reform of the legal system towards establishing a 'harmonious society,' the Party announced the policy of 'combining severity with leniency (kuan yan xiangji) in dealing with criminal cases' at the sixth plenary session of the 16th National CCP Congress. This policy is understood as the Party's reflection over its 'striking hard' (yanda) ${ }^{29}$ policy implemented since the early 1980s when it realized that the tendency of (pure) harsh punishment could produce social instability and disharmony. ${ }^{30}$ Requiring 'striking hard' against serious crime but leniency towards 'first offence, causal offence, juvenile crimes and

27 Ibid.

28 See more information on this concept of 'harmonious judiciary' at Xinhua Net [新华网] 'The Supreme People's Court Raised Idea of "Harmonious Judiciary” for the First Time [最高法院首次提出 “司法和谐” 理念]' at http:// news.163.com/07/0107/11/347SD32N000122EH.html (last accessed on 9 March 2012).

29 The 'strike hard' campaign, or yanda, was originally launched in 1981 as a policy to deal with emerging social order crimes, particularly crimes committed by juveniles and 'hooligans' (liumang). In 1983, it developed into an anti-crime campaign that lasted for three years, which resulted in a 'brutalizing effect' as described by Børge Bakken. The 'strike hard' campaign was defined as a political struggle in which the whole society must participate; the death penalty and imprisonment were rampantly used. Afterwards, there were two other 'strike hard' campaigns in 1996 and 2001. See: Børge Bakken, The Exemplary Society: Human Improvement, Social Control and the Dangers of Modernity in China New York, Oxford University Press 2000, 394; Susan Trevaskes, Courts and Criminal Justice in Contemporary China U.K., Lexington Books 2007, 1 and 83-7. In June 2010, the fourth 'strike hard' was launched nationwide resulting from 'the mass's drop of sense of security.' See: Southern Weekend [南方周末] 'The Fourth Strike Hard: Can It Be Like the Previous Ones? [第四次严打：能像过去一样打吗?]' at http://nf.nfdaily.cn/epaper/nfzm/content/ 20100701/ArticelB10005FM.htm (last accessed on 29 November 2010).

30 Susan Trevaskes 'The Shifting Sands of Punishment in China in the Era of "Harmonious Society" (2010) Vol. 32 No. 3 Law \& Policy 333; Benjamin L. Liebman 'Leniency in Chinese Criminal Law? Everyday Justice in Henan' (2014) Columbia Public Law Research Paper 19. 
crimes where the suspects/defendants' subjective culpability was not serious,' 'combining severity with leniency' was enshrined by the Party as 'an underlying criminal policy' in an attempt to sustain social stability and establish a 'socialist harmonious society.' 31

The People's Procuratorates and People's Courts then devoted their efforts to concretize this policy and spell out what it meant for their work. On the 'severity' side, for instance, after three 'strike hard' campaigns in 1983, 1996 and 2001, China launched the fourth one in $2010 ;^{32}$ on the 'leniency' side, one prominent sign is that reconciliation and mediation were especially highlighted by the Supreme People's Procuratorate (SPP) and the SPC in resolving cases involving 'disputes among the people' (minjian jiufen).

In 2006, the SPP issued the 'Opinions of the Supreme People's Procuratorate on Implementing the Criminal Policy of Combining Severity with Leniency in Procuratorial Work'33 (hereafter the '2006 SPP Opinions'). This document states that 'the criminal policy of "combining severity with leniency" is an important policy of the Party and the State, and is an essential guide of the People's Procuratorate to implement the

31 See the interpretation of the 'Decision' by Xinhua Net [新华网] 'Interpret Decisions of the Sixth Plenary Session: Implement Criminal Justice Policy of Combining Severity with Leniency [解读六中全会决定：实施宽严相济的 刑事司法政策]' at http://news.xinhuanet.com/legal/2006-12/09/content_54594 13.htm (last accessed on 7 April 2011).

32 See: Southern Weekend [南方周末] 'The Fourth “Strike Hard” Campaign: The More We Gain, the More Horrible It Is [第四次全国 “严打”成果 越大越可怕]' at http://news.qq.com/a/20100702/000470.htm (last accessed on 21 March 2012); in June 2010, the fourth 'strike hard' was launched nationwide resulting from 'the mass's drop of sense of security.' See: Southern Weekend [南方周末], supra note 29 .

33 Article 20 of the 'Opinions of the Supreme People's Procuratorate on Implementing the Criminal Policy of Combining Severity with Leniency in Procuratorial Work' [最高人民检察院关于在检察工作中贯彻宽严相济刑事司 法政策的若干意见] states that 'we shall stress conflict resolution in dealing with criminal cases. The Procuratorate shall strengthen resolution of the conflict and mediation of the dispute related to the crime, shall take the outcome of dispute resolution and the implementation of any agreement [related to the dispute] as a significant factor in considering a lenient disposition. In a case where there is a direct victim, the People's Procuratorate may request the suspect to apologize to the victim and compensate the victim if it gives a lenient disposition or decides not to prosecute. The People's Procuratorate shall also well explain the decision to the victim to avoid any further petitioning to the judicial authorities [on the part of the victim in this case].' 
laws of the State.' ${ }^{34}$ Therefore, 'the Procuratorates shall strengthen resolution of the conflict and mediation of the dispute related to the crime, shall take the outcome of dispute resolution and the implementation of any agreement [related to the dispute] as a significant factor in considering a lenient disposition.'35 'The People's Procuratorates shall adopt the promotion of social harmony as a major criterion in the examination of procuratorial work.' 36

Article 12 of the '2006 SPP Opinions' further sets out the 'scope' of cases suitable for 'reconciliation' and 'lenient dispositions.' According to this Article, the People's Procuratorates 'shall be lenient in cases of crime triggered by conflicts among the people (minjian jiufen).' 37 'In the case of a minor crime arising from disputes among relatives, neighbours or schoolmates, we [the People's Procuratorates] shall correctly handle case based on the spirit of "better making friends than enemies" and from the angle of conflict resolution.' 38 'In the case of a minor crime in which the suspect has admitted guilt, repented, apologized, actively compensated the loss and obtained the victim's forgiveness or where the two parties have reached and implemented a reconciliation agreement, and where the harm done to society is not serious, we shall make the decision not to arrest or prosecute in accordance with the law.' 39 'If prosecution is necessary, we may suggest a lenient sentence to the People's Court.' ${ }^{4}$

Later in 2010, the SPC also issued its 'Opinions on Implementing the Criminal Policy of Combining Severity with Leniency' (hereafter the '2010 SPC Opinions'). Article 40 of the '2010 SPC Opinions' says that 'in the case of a minor crime such as minor injury crime arising from disputes among the people (minjian jiufen), if the parties reach reconciliation after public prosecution has been initiated and the case been transferred to the Court, the Court shall (yingdang) approve [the reconciliation agreement] and keep it on record.' ${ }^{41}$ 'The People's Court may

34 Article 2 of the 'Opinions of the Supreme People's Procuratorate on Implementing the Criminal Policy of Combining Severity with Leniency in Procuratorial Work' [最高人民检察院关于在检察工作中贯彻宽严相济刑事司 法政策的若干意见].

35 Ibid, Article 20.

36 Ibid, Article 1.

37 Ibid, Article 12.

38 Ibid.

39 Ibid.

40 Ibid.

41 Article 40 of the 'Opinions of the Supreme People's Court on Implementing the Criminal Policy of Combining Severity with Leniency in Procuratorial Work.' 
(keyi) also try to conduct work to facilitate reconciliation in such cases as long as doing so would not violate any legal provisions.' ${ }^{42}$ Article 23 provides that 'if the defendant compensates the victim promptly, admits guilt and shows repentance after committing the crime, this may (keyi) be taken into consideration according to law as circumstances affecting the discretionary sentencing considerations (zhuoding liangxing qingjie). ${ }^{43}$ 'In a crime arising from disputes among the people (minjian jiufen) such as marriage or family disputes, if the victim and his family have forgiven the defendant, this shall (yingdang) be considered as circumstance under which discretional sentencing is allowed.' ${ }^{44}$ Additionally, 'the People's Court shall mediate as much as possible to eliminate disputes and facilitate both parties' reconciliation in private prosecution cases' and in 'civil litigation collateral to criminal proceeding.' 45

According to the '2006 SPP Opinions,' the emphasis on reconciliation serves three ends. It aims to resolve conflicts between suspects and victims, to "prevent new "petitioning related to judicial cases" (she fa shangfang or she su shangfang),' and thereby to be helpful for establishing a 'harmonious society.' 46 The '2010 SPC Opinions' also characterize as desired outcomes of reconciliation or mediation that it should bring a sense of 'closure' (an jie shi liao) and promote a harmonious society. ${ }^{47}$

New criminal justice practices, which, in brief, address criminal cases through reconciliation or mediation between the parties, developed in the context of these 'Opinions'; these practices were given a name of 'criminal reconciliation' (xingshi hejie) ${ }^{48}$ by domestic Chinese scholars and practitioners.

Such an evident shift of judicial reforms has triggered much debate. Some characterize these judicial reforms as the Chinese judicial system's adjustment in accordance with 'Chinese characteristics.' ${ }^{49}$ To people holding this opinion, mediation and reconciliation in the form now increasingly practised in China are based on the people's real needs and

42 Ibid

43 Ibid, Article 23.

44 Ibid.

45 Ibid, Articles 40 and 41.

46 Ibid, Article 20.

47 Ibid, Article 41.

$48 \mathrm{He}$ Yongjun [何永军] 'On Legitimacy and Legalization of Criminal Reconciliation [论刑事和解的合法性与合法化]' (2009) 3 Journal of Kunming University of Science and Technology (Social Science) [昆明理工大学学报 (社会科学版)] 83 .

49 Xia Min [夏敏] 'Closure: A Not Easy Task in Trial [案结事了: 一个不轻松的审判课题]' (2007) 2 China Trial [中国审判] 13. 
emotions, which are lacking in the formal legal system, so that they can resolve conflicts and bring about 'harmony.' For instance, Su Li has argued that the 'liberal reforms of the judiciary are not feasible in China - a country where more than half of the population live in rural places with stable relationships and a very strong tradition of mediation.' 50 According to $\mathrm{Su} \mathrm{Li}$, adjudication cannot resolve disputes, which might further cause difficulties with enforcement of the verdicts, in turn leading to the parties' petitioning. ${ }^{51}$ In this context, mediation is mainly 'the Party's response to the Chinese people's needs and China's reality.' 52 Similarly, Fan Yu argues that 'litigation or law is transplanted from western jurisdictions, so they are somewhat conflicting with China's conditions and traditional culture. ${ }^{53}$ For instance, as maintained by Fan $\mathrm{Yu}$, the value of 'procedural justice' is contradictory to the value of the Chinese traditional justice, which prefers efficiency and convenience, and is also contradictory to the Chinese people's pursuit of 'substantial justice. ${ }^{54}$ In addition, according to Fan, the problems of the judicial system, such as the difficulty with enforcement, judicial unfairness and corruption, which have led to 'disharmony' in society, are to a certain extent caused by the establishment of the 'modern' judicial system implemented in the past three decades; the increasing social unrest has actually shown the public's dissatisfaction with the current judicial system. ${ }^{55}$ In the same vein, Xia Min especially praises mediation's positive effects to society (shehui xiaoguo) - as argued by Xia, 'in some cases, a modest mediation can have better social effects than a good verdict.' 56

In contrast, some other scholars maintain that the judicial reforms under the policy of 'promoting a harmonious society' embody evident resemblances to the revolutionary judicial style adopted in the Mao era, because, as noted by these scholars, in the course of promoting mediation and reconciliation in dispute resolution, rather than referring to China's

$50 \mathrm{Su} \mathrm{Li}$ [苏力] 'Deliberative Justice and the Big Mediation System [关于能动司法与大调解]' at http://article.chinalawinfo.com/Article_Detail.asp? ArticleId=53760 (last accessed on 9 March 2012).

51 Ibid.

52 Ibid.

53 Fan Yu [范愉] The Theory and Practice of Dispute Resolution [纠纷解决的理论与实践] Beijing, Tsinghua University Press [清华大学出版社] 2007, 295.

54 Ibid, 297.

55 Ibid, 294-5.

56 Supra note 49. 
traditional or cultural elements in mediation, the authorities re-embrace the concepts prevailing in the Mao era, mainly including 'the Ma Xiwu adjudication method,' calling for judicial activism in mediating disputes and 'people's judiciary' (renmin sifa), purportedly aimed at 'meeting the people's needs and emotions.' 57 Nevertheless, as the key ramifications of Mao's leading policy of 'mass line,' the essential feature of 'the Ma Xiwu adjudication method' is 'disregard of law and the rule of law,'58 and the 'people's judiciary' is, in fact, the Party's intense and comprehensive control over the judiciary. ${ }^{59}$ The underlying features of the mediation system implemented in the Mao era and how it departs from the rule of law are elaborated in detail in the next section, and in this sense, scholars holding these points have assessed the current judicial reforms towards 'a harmonious society' as an obvious retrogression of the Chinese judiciary, especially in the aspects of judicial independence and judicial professionalism, and they signal the Party's more direct and tight control over the judiciary. For example, as argued by Carl Minzner, the judicial reform 'return the judiciary to its Party-led, populist roots,' and is 'China's turn against law.' 60 Similarly, Jerome Cohen comments on the judicial reform as the Party's "renewal of the simple "mass line,", which had 'discouraged most professional progress' the Chinese legal system made towards 'the rule of law' since the late 1970s. ${ }^{61}$ Leila Choukroune and Antoine Garapon point to the trick of the authorities' claim of 'the people' as the orientation of the current judicial reforms - according to them, the idea of 'One People' is virtually the 'softer version of something common to totalitarian systems,' because it is impossible to say that there exists something like 'One People.'62

57 Benjamin L. Liebman 'Legal Reform: China's Law-Stability Paradox' (2014) Vol. 143 No. 2 Daedalus Spring 99.

58 Li Site [李斯特] 'The Context of the People's Judiciary and the Mass Line [人民司法群众路线的谱系]' in Su Li [苏力] (ed) Law and Social Science [法律和社会科学] Vol. 1 Beijing, Law Press [法律出版社] 2006, 289, 302.

59 See relevant discussions in e.g. Gao Qicai [高其才] Zuo Ju [左炬] Huang Yuning [黄宇宁] Political Judiciary: The People's Court of Hua County in 1949-1961 [政治司法：1949-1961年的华县人民法院] Beijing，Law Press [法律出版社] 2009.

60 Carl F. Minzner 'China's Turn Against Law' (2011) Vol. LIX No. 4 The American Journal of Comparative Law 944-7, 951.

61 Jerome A. Cohen 'The PRC Legal System at Sixty' at http:// www.eastasiaforum.org/2009/10/01/the-prc-legal-system-at-sixty/ (last accessed on 9 March 2012).

62 Supra note 14. 
According to these scholars, such a turn cannot be viewed as serving for 'the Chinese people's needs and China's reality.' Li Site holds that rather than a mostly 'acquaintance-based society' or a 'close-knit' society as described by $\mathrm{Su} \mathrm{Li}$, today Chinese society has changed to a 'society of strangers' based on a market economy. ${ }^{63}$ Hence, a formal and independent judicial system that can address disputes efficiently and fairly would be more suitable than mediation in resolving (most) disputes. ${ }^{64} \mathrm{Li}$ Jianshu argues that the values underlying traditional Chinese culture that support mediation and reconciliation have largely collapsed in China today along with China's opening up and adoption of the market economy, which resulted in significant changes in society, inter alia, a more and more mobile population and increasingly sharp contradictions. ${ }^{65}$ Importantly, scholars have noted that legal reforms promulgated by the Chinese leadership in the 1980s and 1990s in a liberal direction have given rise to 'rights consciousness' in Chinese society. As maintained by Stanley Lubman, the contemporary Chinese society relies more and more on contracts, which 'suggests increasing acceptance of concepts of law-based rights' as well.66 Eva Pils argues, based on observations of citizen-state confrontations in China's 'letters and visits' (xinfang) system, that in contemporary China 'yuan and rights discourse are inextricably connected.' 67 As noted by Teng Biao, the year of 2003 has been widely acknowledged as the hallmark of China's 'rights defence (weiquan) movement.'68

Empirical evidence and statistics which show that, after 30 years' developments of the legal system towards the rule of law, mediation and reconciliation are not preferred by the Chinese people compared with

63 Supra note 58 .

64 Ibid.

65 Li Jianshu [李剑书] 'Three Bottle-necks in the Establishment of the Criminal Reconciliation System in China [中国刑事和解制度构建的三重瓶颈]' in Bian Jianlin [市建林] and Wang Li [王立] (eds) Criminal Reconciliation and an Alternative Procedure [刑事和解与程序分流] Beijing, The Chinese People's Public Security University Press [中国人民公安大学出版社] 2010, 175-8.

66 Stanley Lubman 'Bird in a Cage: Chinese Law Reform after Twenty Years' (2000) Northwestern Journal of International Law \& Business 388.

67 Eva Pils 'Taking Yuan Seriously: Why the Chinese State Should Stop Suppressing Citizen Protests against Injustice' (2011) No. 2 Temple International and Comparative Law Journal 306.

68 Teng Biao 'Rights Defence (weiquan), Microblogs (weibo), and the Surrounding Gaze (weiguan): The Rights Defence Movement Online and Offline' (2012/3) CEFC 29. 
litigation when disputes arise provide further support for these arguments. For instance, in 2008, a domestic Chinese scholar Liang Ping undertook a survey concerning the various dispute resolution mechanisms in China today, including negotiation with the other party privately, mediation under the village or residence committee, mediation under the basic-level judicial office, mediation under the local-level police, the town government of street office (jiedao banshichu), bringing complaints to the relevant administrative department for mediation, and directly bringing lawsuit and petitioning in urban, suburban and rural places. ${ }^{69}$ The result of Liang's survey shows that although 'negotiation with the other party privately' is still the first choice for the respondents in all the studied areas, 'litigation' has been the second choice for the respondents in both urban and suburban areas (only, mediation under the village committee is the rural respondents' second choice). ${ }^{70}$ Also, by examining the ways to conclude civil cases, Fu Hualing and Richard Cullen found that, since 1997, both the number and percentage of mediated cases in the courts nationwide had been declining. ${ }^{71}$ The mediation rates in big cities were dramatically low - for example, in Shenzhen, this rate was only 12 percent in $2001 . .^{72}$

Liang Ping's research further argues that the judicial system built since the 1970s in the liberal direction may not be the reason for the increasing social unrest and the parties' dissatisfaction. As shown in Liang's research, in total 63.1 percent of the respondents expressed themselves 'satisfied' or 'generally satisfied' with litigation and the percentage of 'satisfied' or 'generally satisfied' respondents is just slightly higher for mediation, which is 67 percent. ${ }^{73}$ Concerning the effectiveness of the various mechanisms for resolving disputes, 69.9 percent of the respondents has assessed 'litigation' as 'useful' or 'generally useful' (though the researcher did not explain the meaning of 'useful' in the report), and such percentage was 64.4 percent in mediation. ${ }^{74}$ On the basis of these

69 Donald C. Clarke 'Choice of Dispute Resolution Mechanisms in China' at http://lawprofessors.typepad.com/china_law_prof_blog/2011/08/choice-ofdispute-resolution-mechanisms-in-china.html (last accessed on 11 September 2011)

70 Ibid.

71 Supra note $19,42$.

72 Ibid.

73 Liang Ping [梁平] 'The Establishment of a Diverse Dispute Resolution System [多元化纠纷解决机制的制度构建]' (2011) 3 Contemporary Law Review [当代法学] 122 .

74 Ibid, 124. 
statistics, Liang contends that 'litigation has played a leading role in the whole dispute resolution system.'75

All this research shows that the so-called 'Chinese characteristics' cited by scholars like $\mathrm{Su} \mathrm{Li}$ and Fan Yu as the justification of the increasingly extensive use of reconciliation and mediation by the judiciary may actually not correspond to the reality in China today - instead, there is a greater social need for well-functioning litigation as well as for a judicial system protecting rights and facilitating access to justice.

The authorities may be to some extent aware of these changes as well. Therefore at the central level, as noted above, the policy of 'establishing a socialist harmonious society' is advocated together with the notion of 'rule of law,' even if, as shown above, there exist obvious contradictions in these conceptions, and the practices have indicated a departure from the rule of law. The significant changes in Chinese society brought about by legal reforms towards the rule of law may also imply that a "simple renewal' of or 'retrogression' to the conception or style of judiciary in the Mao era would not be appropriate to understand the recent judicial reforms under the policy of 'promoting a harmonious society.' For example, $\mathrm{Fu}$ Hualing argues that despite political difficulties, public interest lawyers in China have become "more demanding and more challenging. ${ }^{76}$ Eva Pils also observes that even though there are increasing 'dilution and hostility to rights' under the current legal reforms, the rights movements in China show new features of more alignments and refined practices of rights defence (weiquan). ${ }^{77}$ Hence, the real influences of these recent legal reforms in China may be more complex. In-depth studies on the systems launched in the recent judicial reforms under the policy of 'promoting a harmonious society', such as criminal reconciliation, are of great importance to understand the impacts and connotations of the current judicial reforms.

75 Ibid, 123.

76 Fu Hualing 'Challenging Authoritarianism Through Law' in Jean-Philippe Beja, Fu Hualing, Eva Pils (eds) Liu Xiaobo, Charter 08, and the Challenges of Political Reform in China Hong Kong, Hong Kong University Press 2012, 186.

77 Eva Pils 'The Dislocation of the Chinese Human Rights Movements' in Stacy Mosher, Patrick Poon (eds) A Sword and a Shield: China's Human Rights Lawyers Hong Kong, China Human Rights Lawyers Concern Group 2009, 159. 


\subsection{THE MEDIATION SYSTEMS: FROM THE MAO ERA TO CRIMINAL RECONCILIATION TODAY}

As discussed above, some scholars have commented on the overall re-promotion of mediation in the current judicial reform as China's retrogression to the Mao era and a turn against the rule of law. An examination of the mediation systems implemented since the Mao era, in particular in terms of the role of public power and the relationship between public power and individuals in this process, helps to further understand this proposition as well as the connotation of the current judicial reform. The author argues that the historical experience with Chinese mediation practices since the Mao era shows that the parties' rights are likely to be infringed, and that parties are likely to be subject to coercion in a variety of ways.

\subsubsection{Mediation in the Mao Era: Suppressing Disputes in an Attempt to Serve the Party's Policies}

In 1957, along with Mao Zedong's article of 'On the Correct Handling of Contradictions,' contradictions in society were divided into two kinds 'contradictions within the people' and 'contradictions between the people and the enemies.' 78 According to Mao, conflicts within the people can be resolved through the use of 'democracy' such as mediation, whereas conflicts between the people and the enemies should only be resolved through the methods of dictatorship such as "punishment according to law.' 79

Nevertheless, mediation in the Mao era had other functions apart from dispute resolution. ${ }^{80}$ Stanley Lubman has argued that mediation in the Maoist time mainly served to 'articulate and apply the ideological principles, values, and programmes of the Chinese Communist Party and help mobilizing China's people to increase their commitment to Party policies and goals.' ${ }^{81}$

78 Stanley Lubman 'Mao and Mediation: Politics and Dispute Resolution in Communist China' (1967) Vol. 55 No. 5 California Law Review 1306.

79 Stanley B. Lubman Bird in a Cage: Legal Reform in China after Mao Stanford, Stanford University Press 1999, 42.

80 Supra note 78, 1339.

81 Ibid. 
This function characterized mediation as a process suppressing rather than settling disputes between individuals. ${ }^{82}$ Because, according to Lubman, disputes that the disputants themselves regarded as personal matters were imbued with political significance. ${ }^{83}$ The resolution of disputes is thus seen as assisting the implementation of the Party's policies ranging 'from national unity [and] collective living to increased production.' ${ }^{84}$ In mediation, the parties' intentions and grievances were likely to be overwhelmed by those political goals, and this could easily happen due to the power mediators possessed, which came from their 'belonging to the State and Party apparatus' and their close relation to the police. ${ }^{85}$ As a result, disputes could not be really settled and the original problems remained after the end of the mediation. ${ }^{86}$

\subsubsection{Mediation in the post-Mao Era: 'Plastering over' Disputes and Serving the Party's Policies}

During the Cultural Revolution (1966-76), the mediation system was viewed as a method of 'harmonizing classes' (jieji tiaohe), and so it was abolished. ${ }^{87}$ The end of the Cultural Revolution led to an era of reform, in which 'law has risen to greater prominence in the governance of Chinese society than ever before in Chinese history.' 88 In this era, mediation developed in parallel with the legal system and was integrated into the legal framework dispute resolution. ${ }^{89}$ However, according to Stanley Lubman, mediation in the post-Mao era was still 'sporadically linked to specific policies,' only this connection was 'less noticeable than in the Maoist era.' 90 This continuing connection with the Party's policies

82 Ibid

83 Ibid, 1342.

84 Ibid.

85 Ibid.

86 Ibid.

87 Liu Guangan [刘广安] Li Cunpeng [李存捧] 'People's Mediation and Rights Protection [民间调解与权利保护]' in Xia Yong [夏勇] (ed) Towards an Age of Rights [走向权利的时代] Beijing, China University of Political Science and Law Press [中国政法大学出版社] 1995, 290.

88 Stanley Lubman 'Dispute Resolution in China after Deng Xiaoping: "Mao and Mediation Revisit"” (1997) Vol. 11 No. 2 California Law Review 235.

89 Michael Palmer 'The Revival of Mediation in the People's Republic of China (1): Extra-judicial Mediation' in W.E. Butler (ed) Yearbook on Socialist Legal Systems New York, Transnational Publishers 1987, 220.

90 Supra note 88, 294. 
characterized mediation as a programme in which addressing conflicts remained subordinate to abstract and larger political goals. ${ }^{91}$

In a similar vein, Michael Palmer has shown that mediation in the post-Mao era was used to resolve novel problems and conflicts triggered by the Party's new policies in order to maintain social stability and unity, under the expectation of 'nipping trouble situations in the bud' and 'preventing civil cases and minor criminal cases to upgrade to be serious crimes.' 92 Mediation was also used to popularize law (pufa) as the Party's goal.93 Mediation was used by the Party to educate disputants with relevant laws and policies. ${ }^{94}$ However, according to Palmer, the propagation of laws and policies and legal education were actually mostly for 'encouraging social conformity' and conformity with the Party's goals. ${ }^{95}$

Mediators still had the power to coerce the parties to 'mediate' because, according to Palmer, they were 'nominated' by the chairman of local residents' and village committees and were controlled and supervised by the Party. ${ }^{96}$ In mediation, as further argued by Palmer, 'the democratic principles such as voluntary participation, are subordinate to the political priority of maintaining order and discipline,' now that it was much more important for the Party's governance. ${ }^{97}$

\subsubsection{Mediation Today: A (Still) Coercive Process}

In the $1990 \mathrm{~s}$, although the function of people's mediation was lessened, ${ }^{98}$ in cities the People's Mediation Committee was still positioned as the 'eyes of the government.' 99 This means that besides mediating disputes, it was also expected to undertake work relating to almost all the aspects of

\footnotetext{
91 Ibid, 293.

92 Supra note 89, 246.

93 Ibid, 247.

94 Ibid.

95 Ibid, 248.

96 Ibid, 249-51.

97 Ibid.

98 Fan Yu [范愉] Research on Alternative Dispute Resolution [非诉讼纠纷解决机制研究] Beijing, Renmin University of China Publishing [中国人民大学出版社] 2000, 505 .

99 Kang Huaiyu [康怀宇] 'The Current Situation and the Future: An Investigation on People's Mediation from the Microscopic Perspective [现状与前瞻: 人民调解的微观考察]' in Zuo Weimin [左卫民] (ed) Dispute Resolution in the Age of Transformation [变革时代的纠纷解决] Beijing, 北京大学出版社 [Peking University Press] 2007, 135.
} 
a person's ordinary life. ${ }^{100}$ In rural China, mediation remained popular and strong.

In his study of dispute resolution in a Chinese county, Fu Hualing discusses the popularity of mediation and the strong power of mediators in rural China. According to $\mathrm{Fu}$, with the goal and principle of 'stability overwhelming everything,' the Chinese Communist Party required that 'all the conflicts should be controlled and solved within the localities where the conflicts arise.' ${ }^{101}$ Otherwise, officials of that place would be disciplined and their future promotion would be adversely affected. ${ }^{102}$ Mediators, appointed by the local government, therefore had strong motivation deriving from their tasks in politics, to "quarantine conflicts in the locality.' 103

In this context, they made every effort to 'persuade' (zио gongzuo) the disputants to accept their suggested settlement and not to take their case to the courts or the higher levels of governments. ${ }^{104}$ Benefiting from their status as 'state agents' with power, mediators in rural China could easily put pressure on the disputants. ${ }^{105}$

Power and coercion are (even) more evident in judicial mediation conducted by the courts. As argued by Wu Hongyu, judicial mediation in China is neither an alternative to trial, nor an independent system. ${ }^{106}$ Rather, its operation is 'backed up by Courts, and the possible initiation of trial any minute,' so that 'it almost shares everything with the formal proceedings in Courts,' yet lacks the protection of rights required in the trial procedure. ${ }^{107}$ Among all the shared characteristics, the judge's power or authority in the trial, since it stems from his/her function as a state official exercising public power, is most influential for the parties during mediation. ${ }^{108}$ In addition, according to $\mathrm{Wu}$, as 'closure' or 'closing the case' (an jie shi liao), not 'closing the case in accordance with law' is made as the ultimate goal of judicial mediation, judges may sacrifice the

\footnotetext{
100 Ibid.

101 Fu Hualing 'The Politics of Mediation in a Chinese County: The Case Study of Luo Lianxi' (2003) Vol. 5 No. 2 Australian Journal of Asian Law 110.

102 Ibid, 111.

103 Ibid, 122.

104 Ibid, 117.

105 Ibid, 123.

106 Wu Hongyu [武红羽] The Process of Judicial Mediation: From the Perspective of the Relationship Between Judicial Mediation and Judicial Realm [司法调解的生产过程: 以司法调解与司法场域的关系为视角] Beijing, Law Press [法律出版社] 2010, 59.

107 Ibid.

108 Ibid, 146-7.
} 
fairness and voluntariness stipulated by law in order to achieve this ultimate end. ${ }^{109} \mathrm{Wu}$ argues that in fact, "blurring right and wrong in disputes,' 'plastering over' disputes and 'oppressing the comparatively weak or "tractable" party are all commonly adopted ways in mediation to suppress disputes and to reach 'closure.'110 As a result, judicial mediation is actually controlled and dominated by judges, and the parties' rights are easily infringed. ${ }^{111}$

From the discussion above, it is clear that the Chinese mediation system since the Mao era has always been connected closely with State power and the Party's policies. Mediators also always have power coming from their status as state agents or their status in the Party organization.

Donald Clarke argues that once a system is institutionalized, it is almost impossible for it to avoid being controlled by State power, because, according to Clarke, Chinese authorities are 'uncomfortable with the existence of any organization.' ${ }^{112}$ Hence, as argued by Clarke, it is actually not possible for the Chinese government to allow the parties to dominate truly in mediation, to 'revoke rules as they like,' or to come to an agreement that does not conform to state norms. ${ }^{113}$ Stanley Lubman argues that as long as "mediation remains available to the Party-state as an instrument of policy, mediators may subordinate the parties' rights to some larger political objectives.' ${ }^{114}$

The features of the mediation system in China since the Mao era raise the question as to whether or not, or to what extent, criminal reconciliation could reach the officially purported aims, in particular those concerning the rights and interests of the parties. These aims, as discussed in the following, range from empowering the parties and protecting the parties' rights to giving them a voice in the criminal justice process, to repairing the victim's (psychological) harm and satisfying the parties' expectations. It is also unclear whether or not criminal reconciliation could operate on the basis of voluntariness, and whether or not this process could reach 'harmony' in the Confucian sense, or it is still mainly a tool the Party uses to suppress visible conflicts. All these questions call for an examination of criminal reconciliation practices in China.

\footnotetext{
109 Ibid, 149.

110 Ibid, 150.

111 Ibid, 38.

112 Donald C. Clarke 'Dispute Resolution in China' (1991) Vol. 5 No. 2 Journal of Chinese Law 295.

113 Ibid.

114 Supra note 88, 293.
} 


\subsection{THE IMPLEMENTATION AND DEVELOPMENT OF CRIMINAL RECONCILIATION IN CHINA}

What the author discusses in this section is not limited to practices explicitly called 'criminal reconciliation' (xingshi hejie), because at the point when 'criminal reconciliation' programmes started to be used in some localities in China around 2004, names given to such practices varied from place to place. ${ }^{115}$ According to Song Yinghui, most places called it 'xingshi hejie' (i.e. Hunan province, Beijing municipality, Shanghai municipality and Hainan province); ${ }^{116}$ some called it "pinghe sifa' ('peaceful judiciary') (i.e. Yantai city in Shandong province);117 also some called it 'huifuxing zhengyi' or 'huifuxing sifa', translating from a popular concept in western jurisdictions - restorative justice (i.e. Wuxi city in Jiangsu province). ${ }^{118}$ Nevertheless, according to the author's observation, along with the development of this practice, 'xingshi hejie' (criminal reconciliation) has become the most widely accepted and used name for this mechanism, as well as one later entrenched in the revised Criminal Procedure Law.

When it emerged in China, criminal reconciliation was mainly conducted at the stage of examination for prosecution (shencha qisu) by the

115 Song Yinghui [宋英辉] 'Empirical Analysis on Criminal Reconciliation in Public Prosecution [公诉案件刑事和解的实证分析]' at http://www.sqxb.cn/ blog/blog.aspx?id=309\&zuozeid=83 (last accessed on 27 July 2010).

116 Research Group of 'Empirical Study of Restorative Justice and the Reform of the PRC Criminal Procedure Law' [“恢复性司法与中国 刑事诉讼法改革实证研究' 课题组] 'An Overview of the Current Implementation of Criminal Reconciliation in China [我国刑事和解适用现状之概览]' in Song Yinghui [宋英辉] Yuan Jinbiao [袁金彪] (eds) The Theory and Practice of Criminal Reconciliation in China [我国刑事和解的理论与实践] Beijing, Peking University Press [北京大学出版社] 2009, 35.

117 Wang Chengduo [王成铎] 'Yantai: On the Way of "Peaceful Judiciary" [烟台: 走在 “平和司法” 的大道上] ] at http://www.jcrb.com/n1/jcrb904/ ca477942.htm (last accessed on 24 October 2011).

118 The People's Procuratorate of Wuxi City in Jiangsu Province [江苏省无锡市人民检察院] 'A Summary of Restorative Justice Work in The People's Procuratorates of Wuxi City [无锡市检察机关恢复性司法工作总结]' in Song Yinghui [宋英辉] Yuan Jinbiao [袁金彪] (eds) The Theory and Practice of Criminal Reconciliation in China [我国刑事和解的理论与实践] Beijing, Peking University Press [北京大学出版社] 2009, 97. 
People's Procuratorate. ${ }^{119}$ Gradually, it came to be conducted at the stage of filing a case for investigation (li'an zhencha) by the Public Security Bureau and the trial stage by the People's Court. ${ }^{120}$ And, this programme was first and experimentally conducted by the People's Procuratorate of Chaoyang district in Beijing from 2002.121 Following this so-called 'pioneer' programme, ${ }^{122}$ and especially after obtaining support from the Party's policy of 'promoting a harmonious society' and from the Supreme People's Procuratorate and the Supreme People's Court, more and more places in China started to conduct this programme.

Subsequently, numerous internet reports emerged in China about the growth of this programme. To give some examples, it was reported that from November 2006 to October 2011 that the People's Procuratorates in Hunan province had resolved 4,232 cases through criminal reconciliation; that 6,000 suspects had reached reconciliation with victims; and that 99.5 percent of the agreements reached in criminal reconciliation programmes had been 'smoothly enforced.' ${ }^{23}$ In Hebei province, the police had successfully mediated 3,438 minor injury cases in one year since 2008.124 The People's Court of Chaoyang district in Beijing had started to use criminal reconciliation mainly in the civil litigation proceedings collateral to criminal proceedings since 2005 and formulated its rules for this programme. ${ }^{125}$ In 2006, the No. 1 Criminal Court

119 Cai Guoqin [蔡国芹] Research on Criminal Mediation System [刑事调解制度研究] Beijing, The Chinese People's Public Security University Press [中国人民公安大学出版社] 2010, 233.

120 Ibid.

121 Feng Liqiang [封利强] Cui Yang [崔杨] 'Experience and Problems of Criminal Reconciliation: An Investigation on the Implementation of Criminal Reconciliation in Chaoyang District in Beijing [刑事和解的经验与问题: 北京市朝阳区刑事和解现状]' at http://article.chinalawinfo.com/Article_Detail. asp?ArticleID=42834 (last accessed on 24 October 2011).

122 Ibid.

123 Chen Xuan [陈暄] “4243 Cases Resolved "Privately": The Enforcement Rate of Criminal Reconciliation in Hunan Reached 99.5\% [4243件案子 “私了”：湖南刑事和解案件赔偿履行率达99.5\%] at http:// hn.rednet.cn/c/2009/12/13/1871544.htm (last accessed on 27 July 2010).

124 Ma Jing [马竞] Cao Tianjian [曹天健] 'Hebei Police Successfully Mediated 3438 Minor Injury Cases in Nearly One Year [河北警方 试水轻伤害案件调解处理, 近一年成功调解3438起]' at http://www.criminal law.com.cn/article/default.asp?id=2146 (last accessed on 27 July 2010).

125 Sun Yu [孙瑜] Chen Lei [陈否] 'Solving Criminal Cases Privately: Moving on in Debates [刑事案件私了: 在争议中前行]' at http://news.sina.com. cn/c/1/2007-03-21/160612576540.shtml (last accessed on 26 August 2008). 
Division $^{126}$ of the People's Court of Chaoyang district resolved 327 cases through criminal reconciliation, and 60,000 yuan of compensation had been enforced in these cases. ${ }^{127}$ In 2009, the People's Court in Chun'an county, Zhejiang province solved 302 criminal cases, accounting for 68.42 percent of all the criminal cases, and the number ascended to 553 in 2012, accounting for 87.14 percent of all the criminal cases. ${ }^{128}$

Reports from different places also indicate somewhat imbalanced developments of this programme, while this imbalance shows no direct connection with the degree of economic development of these different regions. For example, in the People's Courts of Aletai city in Xinjiang Uyghur Autonomous Region, criminal reconciliation was used in only 5 out of a total of 16 private prosecution (zisu) cases the Courts heard in 2011.129 The People's Procuratorate of Chaoyang district in Beijing, according to the statistics provided by Feng Liqiang and Cui Yang, used criminal reconciliation in less than 3 percent of all the (suspected) minor

126 According to the Organic Law of the People's Courts of the People's Republic of China, the People's Courts may set up a criminal division, a civil division and an economic division, each with a chief judge and associate chief judges. Normally, in the basic People's Courts and intermediate People's Courts, the criminal division is often divided into No. 1 and No. 2 criminal divisions with division of work. For example, in the No. 2 intermediate People's Court of Tianjin municipality, the No. 1 criminal division is mainly in charge of the first instance trial, and the No. 2 criminal division is mainly in charge of the second instance trial and counter-appeal cases and cases for 'instructions' (qingshi) sent by the lower level People's Courts. See: 'Work Allocation in Tianjin No. 2 Intermediate People's Court [天津市第二中级人民法院审判庭业务划分]' at http://www.huanglawyer.net/Article/ShowArticle.asp?ArticleID=435 (last accessed on 27 October 2011).

127 Ouyang Fang [欧阳芳] 'The Police of Ji'an City in Jiangxi Province Experimentally Conducted Criminal Reconciliation to Promote Social Harmony [江西吉安公安局试行刑事和解制度,促社会和谐]' http://www.chinapeace.org. cn/zhzl/2009-08/24/content_82878.htm (last accessed on 27 July 2010).

128 Chun'an Court Research Group [淳安法院课题组] 'Fieldwork on the Application of Criminal Reconciliation Procedure: Using Chun'an Court's Judicial Practice as a Sample [关于刑事和解程序适用问题的调研: 以淳安法院司 法实践为样本]' at http://www.hzcourt.cn/art/2015/6/3/art_51_12392.html (last accessed 2 October 2015).

129 Zhang Guochen [张国臣] 'The People's Courts in Our City Implemented Criminal Reconciliation Actively to Resolve Social Conflicts [市法院充分运用刑事和解: 积极化解社会矛盾]' at http://www.alt.gov.cn/ Article/ShowArticle.aspx?ArticleID=44190 (last accessed on 27 October 2011). 
injury cases in 2006. ${ }^{130}$ From 2007 to 2008, the People's Procuratorates in Hunan province adopted criminal reconciliation programmes in merely 3.55 percent of all the cases dealt with by these Procuratorates. ${ }^{131}$ The police of Ji' an county in Jiangxi province reportedly resolved 89 minor intentional injury cases through criminal reconciliation in three years between 2006 and 2009. ${ }^{132}$

Although for a long period there were no procedural regulations or guidelines on the operation of criminal reconciliation at the central level, as is common in Chinese legal practice, a number of regulations or guidelines were issued by local authorities, most often the People's Procuratorates and in some places jointly by the Public Security Bureau, the People's Procuratorate, the People's Court and the Justice Bureau. ${ }^{133}$

Some local regulations or guidelines can be accessed on the internet ${ }^{134}$ or have been appended to monographs or books. ${ }^{135}$ Yet some of them are still not publicly available, and are not permitted to be made publicly available. Taking the author's experience by way of example, in two fieldwork locations, the officials approached for copies of their local guidelines on criminal reconciliation simply declined to make them available, even for the purpose of anonymous research. The author was informed that 'these are internal documents' (neibu wenjian) so that they should be 'kept secret' (baomi). However, according to Article 2 of the 'Law of the People's Republic of China on Guarding State Secrets,' state secrets are defined as 'matters that have a vital bearing on state security and national interests and, as specified by legal procedure, are entrusted to a limited number of people for a given period of time.' It is hard to

130 Supra note 121.

131 Tan Zelin [谭泽林] Zhao Qiusheng [赵秋生] 'Problems and Improvements of Laws Accordingly in Implementing Criminal Reconciliation in China [我国刑事和解实施中的问题与相应实体、程序法完善]' (2009) 9 Politics and Law [政治与法律], 149.

132 Supra note 127.

133 Supra note 115, 35-9.

134 For instance, the Regulation issued by Zhuhui district People's Procuratorate of Henyang city in Hunan province can be found at http://www.hyzhq. gov.cn/ZWXX/StandAuthorityColumInfo.aspx?id=475 (last accessed on 1 November 2011).

135 For instance, the Procedural Regulations on the Implementation of Criminal Reconciliation issued by Chaoyang district and Haidian district People's Procuratorates in Beijing were enclosed as an appendix of the book Criminal Reconciliation [刑事和解] by author Wang Yijun [王一俊] and published by the China University of Politics and Law Publishing [中国政法大学出版社] 2010. 
believe that guidelines for criminal reconciliation can be said to fall within these 'matters.' On the contrary, procedural regulations for the criminal reconciliation process, as a regulation over a legal process, should be open. ${ }^{136}$ This belongs to 'access to all relevant information,' which is one of the minimum requirements for the 'right to a fair trial' as confirmed in the Universal Declaration of Human Rights and International Covenant on Civil and Political Rights. ${ }^{137}$ In practice, given the abovementioned restrictions, it is likely that the parties participating in this process may have detailed knowledge and no way of obtaining information about the procedure of criminal reconciliation, as well as their rights to this process. This raises questions as to the process and effect of criminal reconciliation concerning the parties' roles and rights.

Based on their knowledge of available regulations and guidelines on criminal reconciliation in various locations across China, many Chinese scholars have interpreted the procedure as following a similar style and including four steps - initiation, criminal reconciliation meeting, the officials' decision and follow-up programmes (optional). ${ }^{138}$ These steps or stages in the procedure are now also reflected in the Supreme People's Procuratorate's 'Opinions of the Supreme People's Procuratorate on the Handling of Minor Criminal Cases when the Parties Have Reached Reconciliation' issued in December 2010. ${ }^{139}$ These four steps are set out

$136 \mathrm{Xu}$ Bin [许斌] 'Laws and Regulations Should Be the Products of Open Game [法律法规应该是公开博峦的产物]' at http://www.china.com.cn/news/ comment/2010-07/30/content_20607709.htm (last accessed on 6 March 2012).

137 See: Equality and Human Rights Commission 'The Right to a Fair Trial' at http://www.equalityhumanrights.com/advice-and-guidance/before-the-equalityact/guidance-for-service-users-pre-october-2010/criminal-justice-system/theright-to-a-fair-trial/ (last accessed on 6 March 2012).

138 At present, almost all the places with the practice of criminal reconciliation have stipulated local regulations governing the procedure of this practice. See: Song Yinghui [宋英辉] Yuan Jinbiao [袁金彪] (eds) The Theory and Practice of Criminal Reconciliation in China [我国刑事和解的理论与实践] Beijing, 北京大学出版社 [Peking University Press] 2009, 35-9. Some of them can be searched on the internet like the 'Regulation on the Implementation of Criminal Reconciliation in Hunan Province' at http://www.fgw.czs.gov.cn/jcy/ lwxjcy/wjfb/content_988.html (last accessed on 6 March 2012). Some are shown in academic work like the Regulations in Nanjing and Changzhou city, which are enclosed in Di Xiaohua [狄小华] Liu Zhiwei [刘志伟] (eds) The Theory and Practice of Restorative Justice in Juvenile Cases [恢复性少年司法理论与实践] Beijing, People Publishing [群众出版社] 2007.

139 See the interview with Bai Quanmin, the spokesman of the Supreme People's Procuratorate about the 'Opinions' at http://www.lianghui.org.cn/2011/ 2011-03/12/content_22119264_2.htm (last accessed on 15 March 2011). 
below where the term 'party' refers to the suspect/defendant and the victim (or alleged victim) in a case.

\subsubsection{The Stage of Initiation}

Criminal reconciliation can be initiated in three situations. First, the Public Security Bureau/People's Procuratorate/People's Court initiates it based on examining the circumstances of the case and asking both parties whether they agree to participate in criminal reconciliation. ${ }^{140}$ This means that both parties should voluntarily participate in this process. ${ }^{141}$ This type, mainly dependent on official initiation, is the one currently implemented in most places in China and also the one laid down in the 2012 CPL (except that the 2012 CPL requires only the victim's voluntary participation).

Second, the Public Security Bureau/People's Procuratorate/People's Court initiates it according to either party's application. Upon this application, the police/prosecutors/judges should examine the case and make sure that the other party (in other words, it also requires that criminal reconciliation should be based on both parties' voluntary participation) also agrees to participate voluntarily. ${ }^{142}$ An example of this situation is the one adopted in Shanghai municipality. ${ }^{143}$

Third, the parties have reached an agreement themselves, and submit the agreement to the Public Security Bureau/People's Procuratorate/ People's Court for examination. ${ }^{144}$ In this third case, initiation is not really triggered by the authorities; they merely confirm the result of a negotiation process carried out by the parties themselves. An example of this situation is the one adopted in Hunan province. ${ }^{145}$

Not all cases qualify for criminal reconciliation. Official examination of cases centres on:

140 Supra note 119, 232.

141 Supra note 115.

$142 \mathrm{Li}$ Ping [李萍] Liu Yu [刘宇] 'Discussion on the Establishment of Criminal Reconciliation System in Juvenile Cases in the People's Procuratorate [检察机关构建末成年人刑事和解制度探讨]' at http://www.shjcy.gov.cn/njcgy d2007/llsj/t20070809_33593.htm (last accessed on 12 February 2011).

143 Ibid.

144 Supra note 119, 232.

145 San Xiang Municipal Newspaper [三湘都市报] 'Hunan Tried Criminal Reconciliation: Minor Criminal Cases Can Be Reconciled Privately [湖南试行刑事和解制: 轻微刑事案件可私下和解]' at http://www1.china.com. cn/policy/txt/2006-11/22/content_7393033.htm (last accessed on 11 February 2011). 
1. Whether or not the case is suitable for reconciliation. Normally, the case ought to concern a suspected 'minor crime' according to the PRC Criminal Law ${ }^{146}$ and the suspect/defendant should not be a recidivist (in the event of conviction of the crime of which she/he is suspected). ${ }^{147}$ It could be seen that the 'scope' of the cases eligible for criminal reconciliation stipulated in these local regulations or guidelines is wider than that in the 2012 CPL. Usually, criminal reconciliation is preferred in juvenile cases and cases in which the parties have some relationship established before the 'crime,' for instance because they are classmates, neighbours or relatives; ${ }^{148}$

2. Whether or not the parties' application or personal agreement is legitimate, namely it should be both parties' true intentions; ${ }^{149}$ and

3. The suspect/defendant has to admit guilt (renzui) before entering a criminal reconciliation programme. ${ }^{150}$ In some places, the suspect/

146 According to Article 1 of the Judicial Interpretation on CPL issued by the Supreme People's Court [最高人民法院关于执行《中华人民共和国刑事诉讼 法》若干问题的解释] stipulated in 1998, eight categories of crimes are 'minor crime.' They are: intentional injury crime according to Section 1, Article 234 of the PRC Criminal Law; illegal intrusion into others' residence according to Article 245 of the PRC Criminal Law; infringement of other citizens' right of communication freedom according to Article 252 of the PRC Criminal Law; bigamy according to Article 258 of the PRC Criminal Law; abandonment according to Article 261 of the PRC Criminal Law; manufacturing and selling fake and shoddy goods according to Section 1, Chapter 3 of the PRC Criminal Law (except those that seriously undermine social order and state interest); infringement of intellectual property rights according to Section 7, Chapter 3 of the PRC Criminal Law (except those that seriously undermine social order and state interest); crimes stipulated in Chapters 4 and 5 of the PRC Criminal Law which could be sentenced with a punishment lighter than three-year imprisonment.

147 But in some places, criminal reconciliation has been also applied to felonies like serious intentional injury crimes and even death penalty cases. See: Song Yinghui [宋英辉] 'An Empirical Analysis of Criminal Reconciliation in China [我国刑事和解实证分析]' (2008) 5 China Legal Science [中国法学], 124-5.

148 Ibid.

149 Supra note 119, 233.

150 Supra note 119,232 . In practice, it was required in some local regulations or guidelines (i.e. the one stipulated by the People's Procuratorate of Chaoyang district in Beijing and the one stipulated by the People's Procuratorate of Yuhua district in Shijiazhuang). See: the empirical research reports collected in Song Yinghui [宋英辉] Empirical Research on Criminal Reconciliation [刑事和解实证研究] Beijing, Peking University Press [北京大学出版社] 2010, $25,219,237$. It can also be found as the premise of initiating a criminal 
defendant has also to show remorse (huizui biaoxian) for the accused crime. ${ }^{151}$

\subsubsection{Criminal Reconciliation Meeting}

When criminal reconciliation is initiated by one of the State institutions, a criminal reconciliation meeting is expected to be held (arranged for and presided over) by the official. ${ }^{152}$ Most of the regulations or guidelines explicitly emphasize that the criminal reconciliation meeting should proceed on the basis of fairness and voluntariness. ${ }^{153}$ The potential tension arising from official roles and the principle of voluntariness turned out to be a major issue in the empirical study whose results are discussed in later chapters.

The criminal reconciliation meeting can be presided over by the responsible official (i.e. the police/prosecutor/judge concerned with handling this case) or by a people's mediator assigned by the responsible official. ${ }^{154}$

The main work of the official or mediator is to guide and facilitate the parties to reach an agreement. The official or mediator is forbidden to interfere with the parties' own wishes in criminal reconciliation meetings. ${ }^{155}$ The criminal reconciliation meeting can be attended by both parties (or their agents ${ }^{156}$ ); it can also be attended by their relatives and

reconciliation programme in the Guidelines on the Implementation of Criminal Reconciliation in Wuxi city. See the full text of this Guideline in Bian Jianlin [市建林] Wang Li [王立] (eds) Criminal Reconciliation and an Alternative Procedure [刑事和解与程序分流] Beijing, The Chinese People's Public Security University Press [中国人民公安大学出版社] 2010, 452.

151 An example is the Regulation on the Criminal Reconciliation Programme in Changzhou city enclosed in Di Xiaohua [狄小华], Liu Zhiwei [刘志伟] supra note 138 .

152 Xiao Shiwei [肖仕卫] “"The Third Realm” in Criminal Justice: An Analysis of the Structural Position and Function of Criminal Reconciliation in China [刑事法治的 “第三领域”: 中国刑事和解制度的结构定位与功能分 析]' (2007) Vol. 19 No. 6 Peking University Law Journal [中外法学], 724-5.

153 Supra note 119, 236.

154 Chen Ruihua [陈瑞华] 'Private Cooperation in Criminal Proceedings: The Emergence of Criminal Reconciliation in China [刑事诉讼的私力合 作模式: 刑事和解在中国的兴起]' (2006) 5 China Legal Science [中国法学], 16-18.

155 Ibid.

156 'Agents' means persons entrusted by victims, or victims' legal representatives or near relatives. 
other people (i.e. other officials and the parties' friends, teachers, employers, neighbours, or lingdao ('leadership')157). ${ }^{158}$

Generally, a criminal reconciliation meeting is expected to be conducted according to the following four steps. ${ }^{159}$ First, the official or mediator briefly introduces the case to the participants. Second, the suspect/defendant states his/her attitudes to and feelings on the alleged offence, and then admits guilt, expresses regret, apologizes and expresses his/her willingness to compensate the victim voluntarily. Often, as indicated by some scholars, the official would also ask the suspect/ defendant to indicate his/her resolutions for the future in the meeting. Third, the victim expresses his/her feelings and describes the harm and loss caused by the accused crime and then shows forgiveness and the voluntary acceptance of the compensation offered by the suspect/ defendant. Finally, the parties sign an agreement that reflects the oral agreement reached in the meeting (or that may factually have been reached prior to the formal criminal reconciliation meeting).

It appears that the pre-revision criminal reconciliation processes for criminal reconciliation meetings as designed in the local regulations or guidelines were much more detailed and stressed both parties' participation and communication based on their voluntariness, yet these were missing in the 2012 CPL.

\subsubsection{The Official's Decision}

After the suspect/defendant has paid up, the officials in question have different options, depending on the stage at which criminal reconciliation was carried out. The police (Public Security Bureau) can 'dismiss' (chexiao) the case. ${ }^{160}$ The People's Procuratorate may make a decision not to prosecute and to erase the suspect's criminal record, or suggest to the Public Security Bureau that it 'dismiss' the case, or suggest a lenient

157 The phrase 'leadership' (lingdao) is closely related to another phrase '[Party] cadre' (ganbu). The Chinese call people donating leadership skill and capability (or more precisely it is expected that lingdao are skilled/capable persons) in an organizational setup. 'Leader' (lingdao) or 'cadre' (ganbu) is the functionary who staffs the various Party and government bureaucracies and has authority to conduct Party or government affairs. In general, there are three categories of 'leader' (lingdao) or 'cadre' (ganbu): State, local and military. See: James C.F. Wang, Contemporary Chinese Politics New Jersey, Prentice Hall 1995, 119-20.

158 Supra note 119.

159 Supra note 119, 235-6.

160 Ibid. 
sentence to the People's Court. ${ }^{161}$ The People's Court can give the defendant a lenient sentence. ${ }^{162}$ The 2012 CPL follows these options, except that the police are not allowed to directly 'dismiss' the case.

If the parties cannot reach or comply with the criminal reconciliation agreement, the case is transferred back to the normal criminal procedure. ${ }^{163}$

\subsubsection{Follow-up Programmes}

After the criminal reconciliation meeting, the official in charge may arrange for some follow-up work. This may consist in a programme called 'community correction' (shequ jiaozheng) or in a programme called 'help and teaching' (bangjiao) for the suspect/defendant. ${ }^{164}$ In the follow-up work, the official continues to gather information about the suspects/defendants' conduct in daily life, for instance by visiting or calling them or their families regularly. ${ }^{165}$

'Community correction,' according to the 'Opinions on the Nationwide Trial Implementation of Community Correction' issued jointly by the Supreme People's Court, the Supreme People's Procuratorate, the Ministry of Public Security and the Ministry of Justice, is a type of noncustodial criminal punishment. ${ }^{166}$ According to these Opinions, it means 'correcting the criminals in their respective community ${ }^{167}$ with the

161 Ibid.

162 Supra note $116,38-9$.

163 Supra note $119,236$.

164 Song Yinghui [宋英辉] 'An Empirical Analysis of Criminal Reconciliation in China [我国刑事和解实证分析]' (2008) 5 China Legal Science [中国法学], 134.

165 Supra note 119, 310.

166 According to Article 1 of the 'Opinions on the Nationwide Trial Implementation of Community Correction' [最高人民法院、最高人民检察 院、公安部、司法部关于在全国试行社区矫正工作的意见]. See the English translation of the 'Opinions' at LawInfoChina: http://www.lawinfochina.com/ display.aspx $?$ lib=law\&id=8265\&CGid= $($ last accessed on 6 May 2016).

167 In China, although there are still debates on the criteria to divide community, ordinarily, a certain number of residences that subordinate to a residence committee (juweihui) or sub-district office (jiedao banshichu) can be viewed as a community. See: Xia Jianzhong [夏建中] 'The Concept of Community and the Establishment of Community in Urban China [社区概念与我国城市社区建设] ' at http://www.ccpg.org.cn/Article/Show Article.asp?ArticleID=272 (last accessed on 8 December 2010). According to the 'Opinions on Improving the Establishment of Urban Community' issued by the 
assistance of social organizations (shehui tuanti), ${ }^{168}$ non-governmental organizations (minjian zuzhi) ${ }^{169}$ and volunteers to correct their criminal

Ministry of Civil Affairs [民政部关于在全国推进城市社区建设的意见] promulgated in 2000, 'community' refers to the area under a residence committee (juweihui). According to Article 7 of the 'Organic Law of the Urban Residences Committees of the People's Republic of China' [中华人民共和国 城市居民委员组织法], a residents committee shall be established for an area inhabited by 100-700 households on the basis of the distribution of residents and the principle of facilitating their self-government. The definition of sub-district office (jiedao banshichu), however, is unclear at present. The 'Organic Law of the Sub-District Office' [城市街道办事处组织条例] issued in 1954 provides that 'sub-district office (jiedao banshichu) is set in order to strength residential work in cities and the connections between the government and the residents.' And 'the municipality with more than one million population and city without districts should establish sub-district office.' 'The municipality with more than fifty thousand but less than one million population can establish sub-district office if necessary.' Yet this regulation expired in 2009 and there has been no new regulation on sub-district offices ever since. See: Kunming Daily [昆明日报] "The Organic Law of the Sub-district Office over "50 Years Old" Was Banned, yet New Responsibility Has Not Been Clear yet: The Sub-district Office Is More and More Embarrassed [“50多岁” 的《城市街道办事处组织条例》已 被废止, 但新职责依然不明确: 街道办身份越来越滥炝]' at http://szcg.km.gov. cn/ggxx/news.aspx?id=5371 (last accessed on 28 March 2011).

168 According to the 1998 Regulations on Registration and Administration of Social Organizations [社会团体登记管理条例], 'social organization' (shehui tuanti) means 'non-profit groups voluntarily organized by Chinese citizens in order to realize a shared objective according to their rules.' 'All organizations other than state organs may join social organizations as institutional members.'

169 Non-governmental organization (minjian zuzhi) means a non-profit nongovernment organization. It includes social organization (shehui tuanti), nongovernmental non-enterprise entity (minban fei qiye danwei) and foundation. See: Hong Dayong [洪大用] 'An Initial Research on the Poverty Relief Work by Chinese Non-governmental Organizations [中国民间组织扶贫工作的初 步研究]' (2002) 2 Jianghai Academic Journal [江海学刊] 100. Nongovernmental non-enterprise entities (minban fei qiye danwei), according to the 1998 'Temporary Regulations on Registration and Administration of Non-profit Non-government Organizations' [民办非企业单位登记管理暂行条例], are 'non-profit social organizations established by social organizations, citizens, enterprises and other institutions by means of non-state owned property in order to conduct non-profit social service activities.' Foundation, according to the 2004 'Regulation on Foundation Administration' [基金会管理条例], is 'non-profit legal person established according to this Regulation and through making use of the property donated by persons, legal persons, or other organizations with the purpose of pursuing welfare undertakings.' 
minds and bad behavior within the period determined by the judgment or decision, and to help them return to the society.' ${ }^{170}$

'Help and teaching' programmes are arranged by the responsible official using various resources in society (like volunteers and community workers) to 'educate, help, and supervise' the suspect/defendant. ${ }^{171}$ In the programme, the suspect/defendant is often required to do some voluntary work and keep communicating with the people responsible for the programme. ${ }^{172}$ The person undertaking the programme needs to report on the suspect/defendant's performance to the official. ${ }^{173}$

The time stipulated for these follow-up programmes varies from place to place. Usually, it lasts for several months. If the suspect/defendant gets favourable assessments at the end of this period, the decision made after the criminal reconciliation meeting may be confirmed; otherwise, the decision will be revoked. ${ }^{174}$

Although this stage is designed as an option (decided by the officials) for the procedure of criminal reconciliation in these local regulations or guidelines, it is not mentioned at all in the 2012 CPL. Whether this omission could affect the future conduct of follow-up programmes and its effect and importance on the process is further discussed in Chapters 4 and 5 .

Overall, the procedure designed for criminal reconciliation as shown in the local regulations or guidelines is much more detailed and complicated than in the 2012 CPL. Articles 277 to 279 did not even ask for the suspect/defendant's voluntary participation in this 'reconciliation' process, which is stressed in these local regulations or guidelines and may be the foundation of a genuine reconciliation process.

These regulations or rules on criminal reconciliation also outline some essential differences between this process and the normal criminal

170 Article 1 of 'The Supreme People's Court, the Supreme People's Procuratorate, the Ministry of Public Security, the Ministry of Justice: Opinions on the Nationwide Trial Implementation of Community Correction' [最高人民法院、最高人民检察院、公安部、司法部关于在全国试行社区矫 正工作的意见]. See the English Translation at LawInfoChina: http://www. lawinfochina.com/display.aspx $?$ lib $=$ law $\& i d=8265 \& C G i d=($ accessed on 6 May 2016).

171 Supra note $164,134$.

172 Zhang Jie [张洁] “"Restorative Justice, Criminal Reconciliation, Community Correction": Three Crucial Systems in Juvenile Justice System [“恢复性司法、刑事和解、社区矫正”: 少年司法中的三项重要制度] at http:// www.yffz.org/E_ReadNews.asp?NewsId=1249\&page=2 (last accessed on 13 February 2011).

173 Ibid.

174 Ibid. 
proceedings. The normal criminal procedure in the Chinese legal framework, according to the PRC Criminal Procedure Law, includes five stages, namely 'filing a case,' 'investigation,' 'prosecution,' 'trial' and 'execution.' According to the procedure designed for criminal reconciliation, except for the last stage of execution, criminal reconciliation can be initiated at each of the four stages of the normal criminal procedure. It has the effect of ending the normal procedure at one stage (i.e. the police can 'dismiss' the case at the stage of 'filing a case' or 'investigation'; the prosecutor can decide not to prosecute). It can also continue with the normal procedure after the end of the criminal reconciliation process (i.e. the police/prosecutors make suggestions about lenient dispositions to the prosecutor/judge; the judge gives a lenient sentence).

More essentially, the process of criminal reconciliation is different from the normal criminal procedure because the 1996 PRC Criminal Procedure Law has set the normal procedure as an adversarial system (or a more adversarial system compared with the inquisitorial system as set out in the 1979 PRC Criminal Procedure Law). ${ }^{175}$ This design as an adversarial system has also been on principle preserved by the new CPL, to become effective in January 2013. In designing an adversarial system, the 1996 CPL imposes restrictions on public power and provides protection for the suspect/defendant's rights. Fu Hualing summarizes the multiple main advances the 1996 PRC Criminal Procedure Law had made towards an adversarial system: ${ }^{176}$

In many aspects, the [CPL] Amendment introduces important changes to the previous procedures and significantly redistributes the existing division of powers within the criminal justice system. It restricts police power and the prosecution's discretion. It enhances the position of the court and differentiates the role of judges. It also offers more protection for the rights of the accused and enhances the position of defence lawyers in the criminal process in substantive and procedural aspects. Consequently criminal lawyers are expected to play a more active and meaningful role in criminal defence.

Also, at trial, in contrast to the very active role to 'pursue truth' (through pre-trial investigation, and so on) under the generally inquisitorial system

175 Randall Peerenboom 'What Have We Learned about Law and Development? Describing, Predicting and Assessing Legal Reforms in China' (Spring 2006) Vol. 27 Michigan Journal of International Law 844.

176 Fu Hualing 'Criminal Defence in China: The Possible Impact of the 1996 Criminal Procedural Law Reform' (Mar. 1998) No. 153 The China Quarterly 31. 
laid down in the 1979 CPL, 177 judges under the current (more) 'adversarial system' serve a 'more neutral and independent role' during the process. ${ }^{178}$

However, as showed above, criminal reconciliation is essentially based on the two parties' communication and negotiation. That is to say, the two parties are not supposed to stand in 'adversarial' positions in criminal reconciliation processes. As a 'reconciliation' process, voluntariness (from both parties, or only the victim as problematically stipulated in the 2012 CPL) is the basic and core principle underlying criminal reconciliation. The officials' role is also very different: they still have power (i.e. in initiating this process, presiding over criminal reconciliation meetings and deciding the case), so that rather than restricting their discretion as required in the normal procedure, the proceeding of criminal reconciliation heavily relies on their discretion. Furthermore, criminal reconciliation is based on the suspect/defendant's admission of guilt (or showing remorse) beforehand, which is the key issue to establish in the normal procedure.

Although there remain crucial deficiencies in the design of an adversarial system in the 1996 CPL (e.g. no 'presumption of innocence'), and judicial practices in China have been disappointing (or even displaying a reverse picture) in enforcing the CPL (as an adversarial system), ${ }^{179}$ such differences in the designation of these two procedures may still have two further implications: first, it seems that the roles of the official and the parties are distinct from those in the normal criminal procedure. Then, what exactly are their roles in criminal reconciliation processes and what are the interactions between their roles? Second, without the mechanisms involved in the adversarial system serving to restrict the public power and protect the rights of the accused, can the suspect/defendant's (and the victim's) rights be protected in criminal reconciliation processes? Especially, could the most basic principle of voluntariness be guaranteed in criminal reconciliation when public power is supposed to take an active role? These questions indicate the need to look into the operation of this procedure in practice.

177 Mike McConville et al, Criminal Justice in China: An Empirical Inquiry Cheltenham, UK and Northampton, MA, USA, Edward Elgar Publishing 2011, 10-11.

178 Jennifer Smith, Michael Gompers 'Realizing Justice: The Development of Fair Trial Rights in China' at http://www.law.upenn.edu/journals/ealr/articles/ volume2/issue2/SmithGompers2ChineseL.\&Pol\%E2\%80\%99yRev.108(2007).pdf (accessed on 10 January 2010).

179 Supra note 167, 10-12. 


\subsubsection{Recent Developments of Criminal Reconciliation}

In 2007, the Party staged 'big mediation' ( $d a$ tiaojie) in the judicial system. According to the 'Opinions on Deeply Promoting the Resolution of Social Conflicts, the Innovation of Social Management, and the Fairness and Integrity of Law Enforcement' issued by the CCP Central Political and Judicial Committee (zheng fa wei) and the CCP Central Leading Group of Stability Maintaining Work in 2010, 'da tiaojie' refers to mechanisms 'established by Party Committees and governments at all levels' to 'coordinate political, legal, comprehensive governance (zonghe zhili), stability maintenance, petitioning departments for involving the participation of society, and thereby to allow people's mediation, administrative mediation and judicial mediation fully to play their roles and cooperate with each other.' ${ }^{180}$ Accordingly, 'big' in this mechanism refers to the mobilization of all elements and resources in society with the aim of using mediation to resolve as many cases as possible. ${ }^{181}$ This asks for an even wider coverage of mediation in the Chinese judicial system. ${ }^{182}$

In this context, criminal reconciliation has three further developments - although, none of these developments were provided in laws and are prima facie in tension with constitutional principles. First, it has been used in suspected cases of 'serious crimes' including even death penalty cases. For instance, official media reported that in Jiangsu province, criminal reconciliation had been used to deal with serious intentional injury crimes occurring among inmates in prison. ${ }^{183}$ It was also reported that Dongguan city in Guangdong province, Jinhua city in Zhejiang

180 中央政法委员会、中央维护稳定工作领导小组关于深入推进社会矛盾 化解、社会管理创新、公正廉洁执法的意见 [Opinions of the Central Political-Legal Committee, the Central Leading Group of Maintaining Stability On Promoting Social Conflicts Resolution, Innovating Social Management and Fair and Incorrupt Legal Enforcement], See the full text (Chinese version only) at http://www.dffy.com/faguixiazai/ssf/201105/22812.html (last accessed on 8 November 2011).

$181 \mathrm{Wu}$ Zhiming [吴志明] Lin Huabin [林化宾] Wu Junying [吴军营] (eds) The General Mediation System: The Eastern Experience of Responding to Social Conflicts [大调解: 应对社会矛盾凸显的东方经验] Beijing Law Press [法律出版社] 2010, 30-31.

182 Ibid.

183 Jiang De [蒋德] Wan Zhong [万众] 'Criminal Reconciliation Has Been Introduced into Prison: The Judge Says that It Is Not Illegal Leniency [狱内伤害案引入刑事和解: 检察官称绝非法外施恩]' at http://news.sohu.com/ 20090721/n265364272.shtml (last accessed on 22 July 2009). 
province and Shanghai municipality had all used criminal reconciliation in death penalty cases, in which the judges gave the defendants lighter sentences due to their reconciliation with the victim's families and prompt payment of compensation. ${ }^{184}$ Between 28 July and 4 August in 2009, the official newspaper Legal Daily reported five death penalty cases released by the Supreme People's Court - although none of them expressly referred to the phrase 'xingshi hejie,' it could be found that criminal reconciliation, in particular, compensation, had played a significant role in the Supreme People's Court's decision of not approving the death penalty. ${ }^{185}$

Second, there has been a 'duijie' or 'liandong' (collaboration or coordination) mechanism in conducting criminal reconciliation, which refers to mechanisms whereby different state authorities collaborate in implementing criminal reconciliation programmes. In one form of duijie or liandong, the Public Security Bureau, the People's Procuratorate and the People's Court work together in conducting criminal reconciliation. This means that a case may be mediated by the police, the prosecutors and the judges throughout the criminal process from investigation and prosecution to trial and execution. If reconciliation cannot be reached by one organ or in one phase, efforts to achieve reconciliation will be continued after the case proceeds to another phase. According to the saying of the Public Security Bureau/the People's Procuratorate/the People's Court implementing this form of duijie or liandong, this collaboration aims to provide the parties concerned with every opportunity to reach a reconciliation agreement at any point during the criminal procedure. ${ }^{186}$ In the other form of duijie or liandong, the Public Security

184 Sun Wanhuai [孙万怀] 'Do Death Penalty Cases Need Reconciliation and Can They Be Reconciled? [死刑案件可以并需要和解吗?]’ (2010) 1 China Legal Science [中国法学] 180-81.

185 Wang Dong [王栋], Zhao Bin [赵斌] 'Main Problems Facing Criminal Reconciliation and Strategies [刑事和解面临的主要问题与对策] at http:// www.hongfan.org.cn/projects.php?optionid=377\&auto_id=29 (last accessed on 7 August 2015).

186 Ouyang Fang [欧阳芳] 'The Police of Ji'an City in Jiangxi Province Experimentally Conducted Criminal Reconciliation to Promote Social Harmony [江西吉安公安局试行刑事和解制度,促社会和谐]' at http://www.chinapeace. org.cn/zhzl/2009-08/24/content_82878_2.htm (last accessed on 27 July 2010); The People's Procuratorate of Wuhua District in Kunming City [昆明市五华区检察院] 'Cooperation Among Departments and Between the People's Procuratorate and the People's Court Promotes Criminal Reconciliation in Our Court [我院 “部门联动检调对接” 积极促进刑事和解]' at http://www. kmwh.gov.cn/kmwh/web/jwb/j5/jcy/showdoc.jsp;jsessionid=Ot51m9BDkebtjnp8 
Bureau/the People's Procuratorate/the People's Court coordinate with the People's Mediation Committee (renmin tiaojie weiyuanhui), an entity that exists outside the formal court system and is generally used to mediate civil disputes, in conducting criminal reconciliation. Normally, the official informs the parties of the choice of criminal reconciliation if he/she thinks that the case concerned is eligible for this programme. If the parties agree, the case will be transferred to the People's Mediation Committee (this may be the one where the case occurred, or where the victim/suspect is based ${ }^{187}$ ). The Mediation Committee will conduct mediation in a certain period; wherever an agreement can or cannot be reached within this period, the case concerned will be transferred back to the state authorities for review and decision. ${ }^{188}$

Third, it has involved participation from an increasingly wider circle of persons in the criminal reconciliation meeting. For instance, the People's Court in Foshan city in Guangdong province invited prosecutors, members of the National People's Congress, and public media to attend criminal reconciliation meetings. ${ }^{189}$ This wide participation in criminal reconciliation meetings, according to an official of this Court, was to oversee (the judges' conduct) in criminal reconciliation. ${ }^{190}$ It was also reported that the People's Procuratorate in Suining city in Sichuan province authorized victims to select and nominate members of the

RzU7mU9Qmv9bnuDjlMTimcwXMvfFgfOVXroz!742181009?docid=D105138 \&fieldid=F3792 (last accessed on 25 October 2011).

187 The Justice Bureau of Haishu District [海曙区司法局] 'Haishu District Has Reached Perfect Collaboration Between Criminal Reconciliation and the People's Mediation [海曙区实现刑事和解与人民调解工作无缝对接]' at http:// www.zjsft.gov.cn/art/2011/8/8/art_61_31321.html (last accessed on 25 October 2011).

188 Fei County of Linyi City in Shandong Province [山东省临沂市费县] 'Measures on Establishing Collaboration Between Criminal Reconciliation and People's Mediation [关于建立刑事和解与人民调解对接机制的实施办法]' at http://fxzfw.cn/News_View.asp?NewsID=438 (last accessed on 25 October 2011).

189 Yan Xiaoguang [闹晓光] 'Criminal Reconciliation Conducted by the People's Court of Foshan City of Guangdong Province Triggered Debates: It Was Criticized as “Avoiding Punishment with Money” [广东佛山法院刑事和解引 争议: 被指 “以钱买刑” ]' at http://news.163.com/10/0730/00/6CQ5UU5R00 01124J.html (last accessed on 23 July 2010).

190 Ibid. 
People's Congress they trusted as supervisors in their criminal reconciliation programmes. ${ }^{191}$ This was done, according to the official reports, also for the purpose of supervising (jiandu) the official's use of power in criminal reconciliation processes. The prosecutors in charge in Suining said that the involvement of members of the People's Congress could 'expose their work and power to the sunshine' and 'connect work of the People's Procuratorate with the People's Congress's oversight,' which was 'helpful to obtain the parties' as well as the public's support and trust in implementing criminal reconciliation.' ${ }^{192}$ According to some media reports, such extensive participation in criminal reconciliation might also serve the purpose of education. For instance, it was reported that in Xuzhou city in Jiangsu province, the responsible prosecutor, Prosecutor Ming, had held meetings attended by the juvenile offender, members of the People's Congress, the offender's teachers and parents in order to 'better educate the juvenile suspect.' 193

\subsection{THE SCHOLARLY DEBATES SURROUNDING CRIMINAL RECONCILIATION PROGRAMMES}

Scholarly debates on criminal reconciliation practices in China mainly surround the effects of this programme, namely whether it is a programme helpful for promoting a 'harmonious society' in accordance with officially set aims or beneficial in other ways, or whether it is actually an unfair and involuntary programme doing harm to the parties' rights and justice in the criminal justice processes. This part discusses these debates, and suggests that they fail fully to address the problems with criminal reconciliation.

191 Liu Dehua [刘德华] Wang Li [王莉] Jian Hua [简华] 'The Victim Can Nominate National People's Congress Deputy to Participate in the Criminal Reconciliation Process [哪位代表介入刑事和解? 被害人点名] at http:// news.china.com.cn/rollnews/2010-07/05/content_3023494.htm (last accessed on 28 July 2010).

192 Ibid.

193 Xu Chi [许驰] Liu Xiaohan [刘晓晗] 'Ming Guangchao: Lighting Up the Light in Juvenile Delinquent's Heart [明广超: 点亮失足少年心中的灯]' at http://js.jcrb.com/rwgs/201010/t20101014_454600.shtml (last accessed on 19 March 2012). 


\subsubsection{Positive Appraisals}

Praise in the scholarly work mainly revolves around criminal reconciliation's tangible benefits to all the three parties to the criminal procedure, namely the suspect/defendant, the victim and the officials or state authorities. For instance, according to Ge Lin, criminal reconciliation has effectively allowed the victim to obtain satisfactory (monetary) compensation, largely eased the tension between the parties and raised efficiency in dealing with criminal cases. ${ }^{194}$

In order to support these positive assessments, Ge Lin draws on some data from studies sponsored by state authorities; ${ }^{195}$ some of her information was taken from media reports. ${ }^{196}$ For example, according to $\mathrm{Ge}$, a study of seven basic-level People's Procuratorates in Beijing indicates that the average amount of compensation in criminal reconciliation cases is 18,200 yuan, far more than the amount in minor injury cases decided by the courts, which is only 6,300 yuan. ${ }^{197}$ Ge praises the larger amount of compensation in criminal reconciliation cases as the main reason leading to 'victim satisfaction' and as reducing the tension between the suspect/defendant and the victim.

Moreover, Ge says that according to a study conducted by a Procuratorate of Yima city in Henan province, a minor injury case normally takes 115 to 135 days at the prosecution stage of the criminal process, while it only takes about 90 days in criminal reconciliation if the People's Procuratorate decides not to prosecute, and on average 30 days if the Public Security Bureau decides to withdraw the case directly after it has been mediated successfully. 198

Some other scholars have also addressed these two aspects of criminal reconciliation. For example, Chen Qi applauds the smooth 'enforcement' of compensation in criminal reconciliation cases (i.e. the fact that suspects/defendants will not get lenient treatment until they have paid the

194 Ge Lin [葛琳] On Criminal Reconciliation [刑事和解研究] Beijing, The Chinese People's Public Security University Press [中国人民公安大学出版社] 2008, 301-2.

195 Ibid. As noted, Ge Lin used the information and data provided in the surveys conducted by Beijing Dongcheng district People's Procuratorate and Beijing Chaoyang district People's Procuratorate and the People's Procuratorate of Yima City in Henan Province.

196 Ibid. Ge Lin provides examples taken from the Procuratorial Daily [检察日报] and Chongqing Evening News [重庆晚报].

197 Ibid. The study used by Ge Lin here is conducted by Beijing Dongcheng district People's Procuratorate.

198 Ibid. 
compensation they have promised as part of the compensation agreement) as leading to a resolution of the difficulty with enforcing sentences. ${ }^{199}$ Also addressing the raising of efficiency in dealing with criminal cases, Chen Ruihua says that in some minor criminal cases, like intentional injury 'crime,' evidence is usually very hard to collect, and collecting it requires a great many resources. ${ }^{200}$ Limited resources and the increased number of criminal cases require a more reasonable allocation of existing resources. ${ }^{201}$ A system that could alleviate the prosecutor's and the judge's workload and allow them to put more effort into more serious cases is therefore needed. ${ }^{202}$ Criminal reconciliation, which is able to close minor criminal cases in a shorter period (and with less effort spent), according to Chen Ruihua, is a system serving this end. 203

Ge Lin further praises criminal reconciliation's effect of educating and rehabilitating the suspect/defendant, ${ }^{204}$ a point also supported by many other scholars. ${ }^{205}$ For example, Sun Qin says that in criminal reconciliation cases handled by the People's Procuratorate, the suspect could get

199 Chen Qi [陈颀] 'The Incentive Mechanism of "Reducing Punishment with Money” [“赔钱减刑” 的激励机制]' in Su Li [苏力] (ed) Law and Social Sciences [法律和社会科学] Beijing, Law Press [法律出版社] 2009, 30.

200 Chen Ruihua [陈瑞华] Criminal Proceedings: The Chinese Model [刑事诉公的中国模式] Beijing, Law Press [法律出版社] 2008, 17-19.

201 Ma Mingliang [马明亮] Negotiated Justice: A New Procedural Idea [协商性司法：一种新程序主义理念] Beijing, Law Press [法律出版社] 2007, $1-5$.

202 Supra note 200, 16-17.

203 Ibid.

204 Supra note 194, 302.

205 This viewpoint can be found in much domestic work discussing the values of criminal reconciliation. See: e.g. Sun Qin [孙勤] An Analysis of the Values of Victim-Offender Reconciliation [刑事和解价值分析] Beijing, The Chinese People's Public Security University Press [中国人民公安大学出版社] 2009, 154; Ge Lin [葛琳] On Criminal Reconciliation [刑事和解研究] Beijing, The Chinese People's Public Security University Press [中国人民公 安大学出版社] 2008, 45; Wu Xiaofeng [武小凤] Conflict and Compromise: On Criminal Reconciliation [冲突与对接: 刑事和解刑法制度研究] Beijing, The Chinese People's Public Security University Press [中国人民公安大学出版社] 2008，180-81; Miu Weihui [缪伟辉] “刑事和解的价值提取 [The Values of Criminal Reconciliation]' (2010) 10 Legal System and Society [法制与社会] 20; Xiang Chaoyang [向朝阳] Ma Jinghua [马静华] 'The Establishment of the Values of Criminal Reconciliation and Its Chinese Pattern [刑事和解的价值 构造及中国模式的构建]' (2003) 6 Chinese Legal Science [中国法学] 115. 
the official's decision not to prosecute and thus avoid a criminal record. In cases that have already been transferred to the People's Court, the defendant could normally get a non-custodial sentence if criminal reconciliation is successful. ${ }^{206}$ This, according to Sun, means that the suspect/ defendant could be rehabilitated in society whereas, by contrast, time in prison would make rehabilitation tough. ${ }^{207}$ Zhou Shixiong observes that according to follow-up interviews with juvenile suspects after the conclusion of criminal reconciliation programmes in Hunan province, 100 percent of the juvenile suspects were assessed as 'performing well' in school and 86 percent of them had made obvious progress in study. ${ }^{208}$

Based on the above, Xiang Chaoyang and Ma Jinghua suggest that criminal reconciliation serves the 'value of justice' (gongzheng jiazhi). ${ }^{209}$ This 'value of justice,' according to Xiang and Ma, means that criminal

206 Ordinarily, in a case with the prosecutor's decision not to prosecute, the suspect will still have a criminal record which will affect his/her employment and education, and so on. Also, a person with a criminal record is not qualified for the civil service examination and army enlistment. Article 100 of the PRC Criminal Law stipulates that "when people join the military, or seek employment, those who received criminal punishments according to law should honestly report the punishments they received to the relevant units and should not conceal them.' See the English translation at: http://chinalawtranslate.com/\%E4\%B8\% $\mathrm{AD} \% \mathrm{E} 5 \% 8 \mathrm{D} \% 8 \mathrm{E} \% \mathrm{E} 4 \% \mathrm{BA} \% \mathrm{BA} \% \mathrm{E} 6 \% \mathrm{~B} 0 \% 91 \% \mathrm{E} 5 \% 85 \% \mathrm{~B} 1 \% \mathrm{E} 5 \% 92 \% 8 \mathrm{C} \% \mathrm{E}$ $5 \% 9 \mathrm{~B} \% \mathrm{BD} \% \mathrm{E} 5 \% 88 \% 91 \% \mathrm{E} 6 \% \mathrm{~B} 3 \% 95 \% \mathrm{EF} \% \mathrm{BC} \% 882015 \% \mathrm{E} \% \mathrm{~B} 9 \% \mathrm{~B} 4 \% \mathrm{E} 4 \%$ $\mathrm{BF} \% \mathrm{AE} \% \mathrm{E} 6 \% \mathrm{AD} \% \mathrm{~A} 3 \% \mathrm{EF} \% \mathrm{BC} \% 89 /$ (last accessed on 6 May 2016). Article 24 of the Civil Servant Law of the People's Republic of China stipulates that 'anyone who has been imposed on a criminal punishment shall not be employed as a civil servant.' 'Criminal record system is long deemed as to be helpful for recidivism prevention.' See the English translation at: http://www.pkulaw.cn/ fulltext_form.aspx? $\mathrm{Db}=$ chl\&Gid=58050 (last accessed on 6 May 2016). But in criminal reconciliation, the suspect's criminal record will be expunged together with the decision of non-prosecution, so that the suspect's future life will not be influenced by the record/his past wrongdoing. See: Sun Qin [孙勤] An Analysis of the Values of Victim-Offender Reconciliation [刑事和解价值分析] Beijing, The Chinese People's Public Security University Press [中国人民公安大学出 版社] 154 .

207 Sun Qin [孙勤] ibid.

208 Zhou Shixiong [周世雄] 'On Criminal Reconciliation: Taking the Exploration of Criminal Reconciliation in Hunan Province as an Analytic Sample [也论刑事和解制度: 以湖南省检察机关的刑事和解探索为分析样本]' (2008) 3 Law Review [法学评论] 21.

209 Xiang Chaoyang [向朝阳] Ma Jinghua [马静华] 'The Establishment of the Values of Criminal Reconciliation and Its Chinese Pattern [刑事和解的价值构造及中国模式的构建]' (2003) 6 Chinese Legal Science [中国法学] 114 . 
reconciliation "has balanced the protection of the interests of the [participants in] three roles in criminal procedure, namely the [interests of the] victim, the suspect and the state authorities. This is different from the normal criminal procedure in which the victim is often ignored.'210

In addition to the benefits to the parties and the state authorities, criminal reconciliation is also praised by scholars for meeting the expectations articulated by the Supreme People's Procuratorate and the Supreme People's Court, namely the expectations of bringing 'closure' to criminal cases and preventing 'petitioning related to judicial cases.' Scholars like Chen Ruihua argue that the traditional core goals of the PRC Criminal Law, which he identifies as combating crimes and punishing criminals, cannot resolve the conflict between the victim and the suspect/defendant caused by the crime. ${ }^{211}$ Under the traditional goals, the conflict still exists after the case has been closed, so the parties may be dissatisfied with the judicial system. ${ }^{212}$ The victim would feel more dissatisfied facing a long-standing problem with the Chinese judicial system, namely, it is extremely hard to enforce the court's sentence in cases where a civil dispute about compensation has been joined to the criminal litigation. ${ }^{213}$ These two elements, according to Chen, are the main cause leading to 'petitioning related to judicial cases' (she $\mathrm{fa}$ shangfang or she su shangfang), which has been viewed by the government as a symptom of lack of 'harmony' in society and therefore a phenomenon that needed to be tackled. ${ }^{214}$ Criminal reconciliation, possessing the aforementioned advantage of 'enforcing' compensation obligations, is then praised by these scholars for having the function of closing cases and preventing the parties (mainly the victim) from petitioning. ${ }^{215}$ In practice the statistics seem to support this argument for example, in 2014, the Procuratorate of Huangmei county in Hubei province had conducted criminal reconciliation in 43 cases at the stage of examination for arrest, and there was no appeal or petitioning in those 43

\footnotetext{
210 Ibid.

211 Supra note 200, 19.

212 Ibid.
}

213 Article 77 of the 1996 PRC Criminal Procedural Law provides that if a victim has suffered material losses as a result of the defendant's offence, he shall have the right to file an collateral civil appeals during the course of the criminal proceeding.' However, due to various reasons, usually the victim with the court sentence concerning 'civil compensation' cannot get the sentence enforced. See: Chen Ruihua [陈瑞华] ibid.

214 Ibid.

215 Ibid. 
cases after the Procuratorate decided not to arrest the suspects. ${ }^{216}$ On the eve of the promulgation of the revised Criminal Procedure Law, Chaoyang District People's Procuratorate published their survey on 100 criminal reconciliation cases they had conducted between 2002 and 2012, which showed that 100 percent of the parties (including the victim and the offender) reported satisfaction with criminal reconciliation's justice, and criminal reconciliation had achieved the effectiveness called 'four zeros,' namely, zero recidivism, zero new dispute between the parties, zero lawsuit lodged by a victim out of poor protection of his/her interests, zero appeal and petitioning. ${ }^{217}$

Based on this effect, Chen Ruihua suggests that criminal reconciliation serves 'the value of harmony' (hexie jiazhi), which, according to Chen, comes from its function of restoring relationships in society. ${ }^{218}$ As interpreted by Chen, the 'value of harmony' has nothing to do with either the procedure or outcome of the criminal process; rather, "it is a wholly new value in addition to, as well as "challenging" the traditional two values of procedural fairness and justice of outcomes.' 219

Without further elaboration, however, such a view of a new value is too vague to understand. As a 'challenge' to the values of procedural fairness and justice of outcomes according to Chen Ruihua, is this third value of 'harmony' in contradiction with the other two values (or can it be)? If this is the case, how should we understand the relationship between criminal reconciliation and a rights-centred conception of justice?

Xiao Shiwei and Ma Jinghua argue that criminal reconciliation has shown 'communication between State law and customs in society' by

216 Xiao Zhiyun [肖之云] 'Huangmei: “Two Fast One Trial” Criminal Reconciliation Are Effective [黄梅: ‘两快一审” 刑事和解显成效]' at http:// www.hbjc.gov.cn/ssjd/201509/t20150907_714579.shtml (last accessed on 1 November 2015).

217 Yang Mengchen [杨孟辰] Zhang Shuyang [张舒阳] “北京朝阳检察院十年刑事和解工作当事人满意率 $100 \%$ [Beijing Chaoyang Procuratorate Implemented Criminal Reconciliation for Ten Years 100 Percent of Parties Satisfied]' at http://legal.people.com.cn/n/2012/0926/c42510-19110709. html (last accessed on 1 November 2015).

218 Excerpted from Chen Ruihua [陈瑞华]'s talk collected in Criminal Reconciliation: A Conversation Between Legal Experts and Legal Scholars [刑事和解: 法律家与法学家对话录] at http://www.procedurallaw.cn/xsss/zdwz/ 200807/t20080724_51763.html (last accessed on 24 October 2011).

219 Ibid. 
absorbing the practice of 'resolving crimes privately' (xing'an si liao), which is common in Chinese society, into the legal framework. ${ }^{220}$

'Resolving crimes privately' refers to situations in which 'issues of alleged criminal responsibility that should be processed by judicial organs are simply sorted out by the parties privately.'221 Many scholars, including Xiao and Ma, view this as an ultimately problematic practice. For instance, according to Xiao and Ma, 'xing'an si liao,' even if it could in some cases satisfy both parties, has harmed the interests of the State, since it 'excludes the State's participation in (suspected) criminal cases.' 222 Li Lianfeng and Shang Shumin characterize such 'exclusion' of the State in handling criminal cases as a '[sign of] disregard for and a challenge to the State law and legal policies.' ${ }^{223}$ Chen Yufan and Qu Guangchen express the concern that 'xing'an si liao' may lead to 'hidden trouble' for society by leaving unpunished 'offenders' in society. ${ }^{224}$ Some other scholars note the potential harm of 'xing'an si liao' to the individual parties. For example, Chen Yufan and Qu Guangchen say that coercive 'reconciliation' is very likely to happen in 'si liao' (i.e. when one party has more power and influence). ${ }^{225}$ Zhang Shuqin claims that it has been found that in practice, officials, in particular the police, also play some role in 'si liao,' which might result in rent-seeking, judicial corruption and encourage coercive 'reconciliation.' 226

Yet scholars acknowledge that 'xing'an si liao' is very popular in China. According to Zhang Shuqin, it has been found that, in 2001, 70 percent of the intentional injury cases, theft cases and bigamy cases in

220 Xiao Shiwei [肖仕卫] Ma Jinghua [马静华] 'The Unique Function of Criminal Reconciliation in China: From the Perspective of Resolving the Problem of “Solving Criminal Cases Privately" [中国刑事和解的独特功能: 以刑事案件 “私了” 问题之解决为起点的分析] (2010) 2 Criminal Science [中国刑事法杂志] 63 .

221 Chen Yufan [陈玉范] Qu Guangchen [屈广臣] 'Thoughts on "Private Resolution” [“私了”问题的法律思考]” (1995) 1 Modern Legal Science [当代法学] 24 .

222 Supra note 220, 65.

223 Li Lianfeng [李连峰] Shang Shumin [尚淑敏] 'On the Construction of Criminal Reconciliation System: On the Basis of "Private Resolution" among the People [论我国刑事和解制度的构建: 以民间 “私了” 传统为基础的构建 模式]' (2009) 12 Academic Exchange [学术交流] 83.

224 Supra note 221, 24.

225 Ibid.

226 Zhang Shuqin [张书琴] 'Treating Criminal Reconciliation Rationally [理性对待刑事和解]' (2007) 3 Hebei Law Science [河北法学] 120. 
Leping city in Jiangsu province were solved privately. ${ }^{227}$ Another study conducted by a law firm in Shandong province in 2003 indicates that 25 percent of 'crimes' in rural China have been resolved through this way. ${ }^{228}$ It should be noted, however, that neither of these studies mentions the way in which they collected their data.

Xiao Shiwei and Ma Jinghua do not attribute the popularity of 'xing'an si liao' to the Chinese citizen's ignorance of or disregard for the law, as is often done; they argue that it is due to what they view as incoherence between the State law and social customs, and this needs to be addressed.22 $^{22}$ The way to address it, according to Xiao and Ma, is for the State law to 'critically acknowledge this custom,' which is reached by criminal reconciliation. 230

Some other scholars praise the value of criminal reconciliation from the perspective of traditional Chinese culture. For example, Li Lianfeng and Shang Shumin say that "the popularity of "xing'an si liao" reflects a value of Chinese culture and embodies Confucian ideas of "no litigation" (wu song) and "valuing peace" or "valuing harmony" (he wei gui),' so it is worthwhile to have a system like criminal reconciliation in the legal framework to address such practices. ${ }^{231}$ Several scholars even suggest learning from what they describe as a customary Tibetan law:232

After offences like murder and intentional injury, the parties do not resort to any judicial authority; they would invite agencies with [high social] standing to help them communicate with each other and invite members of their families to discuss and assess the loss in the case, and then to resolve the cases through reconciliation and compensation.

This compensation is aptly called 'pei ming jia' ('赔命价' or literally 'the price for [a] life') or 'pei xue jia' ('赔血价' or literally 'blood price') in the work just cited. 233

Therefore, in these scholars' opinions, criminal reconciliation is a system showing the State law's adoption of customs that have always existed in Chinese society, while at the same time 'overcoming the

\footnotetext{
227 Ibid.

228 Ibid.

229 Supra note 220, 24.

230 Ibid.

231 Supra note 223, 83.

232 Ma Congcong [马丛丛] 'An Examination of the Idea of Restorative Justice Embodied in the Customary Tibetan Law [藏族习惯法之现代 恢复性司法理念审查]' (2011) 7 Business Culture [商业文化] 17.

233 Ibid.
} 
shortcomings of xing'an si liao' with participation from and oversight by state authorities. ${ }^{234}$ It is, according to them, of great significance to the establishment of 'the socialist rule of law with Chinese characteristics' and the 'increase of State's capacity of ruling society at the grassroots.' 235

Nevertheless, there might be three problems with this praise. First, as noted in the previous part, criminal reconciliation was initially implemented in comparatively developed locations in China such as Beijing and Jiangsu province, not rural China where the State law is much weaker and customs are much stronger. This calls into question this purported function of 'connecting the State law and customs in society' through criminal reconciliation. Second, criminal reconciliation is conducted in cases handled by the Public Security Bureau/People's Procuratorate/People's Court, namely in cases that have already come into the hands of state authorities. These scholars did not indicate whether this mechanism was able to attract matters potentially to be resolved privately into the state authorities. Therefore, it might be far-fetched to appraise criminal reconciliation as helpful to address the problem of 'xing'an si liao.' Third, the enthusiasm for adopting 'customs' such as 'pei ming jia' or 'pei xue jia' without careful and in-depth examination of these customs and the context in which these customs emerged and existed might be too facile. Also, it might be too facile to assert the value of traditional culture, namely Confucian ideology in the legal framework.

In addition, there is a crucial problem with all these positive appraisals expressed by the scholars - they all build their praise largely on information provided in the Procuratorate/Court's reports. The heavy reliance on official sources raises doubts as to the reliability of the factual basis upon which they make such assessment, given especially that these data were collected at a time when the Procuratorates/Courts in question were expected to participate in the promotion of the Party's 'harmonious society' policies through their contribution to criminal reconciliation. ${ }^{236}$

\subsubsection{Concerns and Criticisms}

In general, criticism and concerns over criminal reconciliation focus on two issues - fairness and voluntariness. Concerning whether or not criminal reconciliation is unfair to economically weak suspects/

\footnotetext{
234 Supra note 220, 67.

235 Ibid.

236 Further discussion of the issue of reliability of official sources can be found in Chapter 3.
} 
defendants, perhaps the most serious problem has been that the main focus of this process is on the amount of compensation to be paid to the victim.

For instance, Ge Lin observes that in practice the payment of compensation has been normally adopted by the official as the most important, or even the only, standard to assess whether or not the parties have achieved mutual understanding, the suspect/defendant is remorseful and has obtained the victim's forgiveness. ${ }^{237}$ According to Ge, rarely could we find that a criminal reconciliation programme ends without the payment of compensation. ${ }^{238}$

Therefore, some comments on criminal reconciliation are along the lines of 'if you have money, you will get a lenient sentence; if you are poor, you will go to prison.' 239 Criminal reconciliation programmes have accordingly been criticized as unfair to the poor, since 'the rich can pay money to avoid punishment' (yi qian shu xing or pei qian jian xing). ${ }^{240}$ Compensation agreed upon in the context of criminal reconciliation has tellingly been called 'reconciliation fee' (hejie fei), and criminal reconciliation has been characterized as a 'trade-off between money and [the victim's] rights' (quan qian jiaoyi). ${ }^{241}$ Further, some scholars have warned that criminal reconciliation like this is actually harmful to the establishment of a 'harmonious society', since it is likely to sharpen contradictions and trigger discontent in society. ${ }^{242}$

Li Ming characterizes criminal reconciliation as a mechanism 'all about money. ${ }^{243}$ And, according to $\mathrm{Li}$, those who like it most are officials, since it could 'largely facilitate rent-seeking and corruption.'244

237 Ge Lin [葛琳] 'An Analysis of the Practical Predicament of Criminal Reconciliation [刑事和解的现实困境解析]' (2010) 5 Justice of China [中国司法] 19.

238 Ibid.

239 Li Hongjiang [李洪江] 'The Implementation of Criminal Reconciliation Should be Slowed Down' [刑事和解应缓行] (2006) 5 Chinese Prosecutors [中国检察官] 13 .

240 Ibid.

241 Shan Shibing [单士兵] 'The "Illusion of Harmony" behind Criminal Reconciliation [刑事和解背后的 “和谐幺]觉” ]' at http://gb.cri.cn/9083/2006/ 11/23/2165@1317252.htm (last accessed on 24 February 2012).

242 Ibid.

243 Li Ming [黎明] “The “All-about-Money” Criminal Reconciliation Is Damage [耍钱的刑事和解是祸水]' at http://news.ifeng.com/opinion/society/ detail_2009_08/18/1303072_0.shtml (last accessed on 5 November 2011).

244 Ibid. 
Yet in the meantime, scholars are arguing that there is no such problem of unfairness in criminal reconciliation. For instance, Zhang Fuxiong says that an exclusive focus on compensation in criminal reconciliation is similar with 'shuxing' (赎刑), a practice which had been adopted in laws in ancient China since the Qin and Han dynasties. ${ }^{245}$ Shuxing translates roughly as 'redemption of punishment' and it was always closely connected to the making of payments by the culprit. Although 'shuxing' is different from criminal reconciliation since it only allows certain privileged categories of persons to 'pay money to avoid punishment,' Zhang argues that the exclusive focus on compensation in criminal reconciliation could be justified by this ancient system in China for its 'absorption of the traditional system.' ${ }^{246}$ Yet by saying this, Zhang does not discuss whether 'shuxing' is a fair and just system. The simple 'absorption' of a traditional system cannot justify the (potential problem of) unfairness of criminal reconciliation.

$\mathrm{Du} \mathrm{Yu}$ also defends criminal reconciliation as a fair process by arguing that 'equality in the sense of law refers to equality of opportunity' and 'criminal reconciliation actually provides this equality of opportunity to all the suspects/defendants. ${ }^{247}$ Besides, the outcomes in criminal reconciliation cases (i.e. withdrawing the case, non-prosecution or suspended sentence) are 'the results of compensating the loss, which indeed shows the suspect/defendant's attitudes and inclination to be good, not of the wealth he/she possesses.' 248

Likewise, Wang Zhixiang and Zhang Weike argue that in criminal reconciliation "money is no more than a signal to show the suspect/ defendant's attitudes and "harmfulness to society" (shehui weihaixing).' 249 And 'whether or not the suspect/defendant can get a lighter sentence is absolutely up to the judge,' who will 'oversee not only the

245 Zhang Fuxiong [张孚雄] 'Thoughts on the Use of Criminal Reconciliation in Serious Crimes [重罪案件刑事和解的理论思考]' (2011) 2 Law and Economy [法制与经济] 185 .

246 Ibid.

247 Du Yu [杜宇] ““Criminal Conciliation”: Critics and Preliminary Response [“刑事和解” : 批评意见与初步回应]' 8 .

248 Ibid.

249 Wang Zhixiang [王志祥] Zhang Weike [张伟珂] 'On the Legitimacy of Criminal Reconciliation in Capital Cases [死刑案件中刑事和解的正当性探究]' (2011) 4 Northern Legal Science [北方法学] 52. 
criminal reconciliation process, but also the other facts and evidence in the case concerned to guarantee the legality of criminal reconciliation cases. 250

In the author's view, however, these justifications are far-fetched and unacceptable. For one thing, it is hard to assert that the suspect/defendant who is too poor to compensate does not truly feel regretful (or even that the poor suspect/defendant is less 'inclined to be good') or has more 'harmfulness to society,' and vice versa. For another, the argument concerning the 'outcome' in compensation is hard to understand - how to make the link between the wealth the suspect/defendant possesses and the amount of compensation he/she ought to pay?

The second main concern with criminal reconciliation is the public power's infringement upon the parties' voluntariness in this process. For instance, Du Yu claims that there are two forms of 'coercion' in criminal reconciliation - one is defined by him as 'obvious coercion,' which means that 'one party with advantages in status, influence or economic conditions may pressurize the other party to "reconcile" through threatening or intimidating [the other party], or buying [them] off etc.'251 Yet $\mathrm{Du}$ thinks that this form of coercion could be effectively addressed through the supervision (jiandu) and examination of the parties' real intentions by the officials. ${ }^{252}$

The other form of coercion the parties may be confronted with in criminal reconciliation is named by $\mathrm{Du}$ as 'subtle coercion.' 253 This 'subtle coercion,' according to Du, may first come from the 'harsh treatment the suspect/defendant thinks may be imposed in the normal criminal procedure' such as arrest and incarceration. ${ }^{254}$ It may also come from the (negative) comments from other people living around the parties or the public opinion. ${ }^{255}$ The third form of 'subtle coercion' in criminal reconciliation processes, according to $\mathrm{Du}$, comes from the officials' 'inducement' (i.e. through exaggerating the risk and adverse impact of the normal procedure, and fabricating information). 256

$\mathrm{Du}$ Yu further contends that the first two forms of 'subtle coercion' could not be said to violate the parties' voluntariness in criminal reconciliation. Because 'in the first case, the parties make their decisions

\footnotetext{
250 Ibid, 44.

251 Supra note 248, 12.

252 Ibid.

253 Supra note 248.

254 Ibid.

255 Ibid.

256 Ibid.
} 
based on a balance of costs and benefits' (i.e. 'how much reconciliation is worth for me to avoid criminal record and punishment'); and in the second case, Du argues that 'although the parties may be influenced, after all they can still make decisions freely.' ${ }^{257}$ Only the third form of 'subtle coercion,' according to $\mathrm{Du}$, has violated the parties' voluntariness. ${ }^{258}$ Because, 'the officials possess absolute advantages in knowledge, information and experience etc. in comparison with the parties in criminal reconciliation,' and in practice, 'the parties are facing the same official if they refuse the officials" "suggestions" in criminal reconciliation,' which is very likely to make the parties feel worried about any adverse outcomes in the criminal case. ${ }^{259}$ Therefore, as argued by Du, it is very hard for the parties to resist the officials' intentions in criminal reconciliation processes, even though they do not want to accept them. ${ }^{260}$

Other scholars also suggest reasons to worry about public power's infringement upon the parties' rights in criminal reconciliation. For example, Chen Weidong observes that criminal reconciliation has actually given 'added power to the officials,' which 'may provide the officials with another opportunity of rent-seeking.'261 Xu Yang expresses concern that this infringement upon the parties' rights and voluntariness by public power is very likely to happen in criminal reconciliation, because 'this programme is now promoted vigorously by the government and has been connected with so many political goals.' ${ }^{262}$ These, according to $\mathrm{Xu}$, are strong incentives for the officials to abuse their power in criminal reconciliation that would harm the parties' voluntariness and rights. ${ }^{263}$

In order to address this problem, scholars are keen on an adequate supervision (jiandu) mechanism to curb the officials' power in criminal reconciliation. ${ }^{264}$ For example, Ge Lin writes: ${ }^{265}$

$\begin{array}{ll}257 & \text { Ibid. } \\ 258 & \text { Ibid. } \\ 259 & \text { Ibid. } \\ 260 & \text { Ibid. } \\ 261 & \text { Chen }\end{array}$

261 Chen Ruihua [陈瑞华] 'Criminal Reconciliation: A Conversation Between Legal Experts and Legal Scholars [刑事和解: 法律家和法 学家的对话]' at http://www.procedurallaw.cn/xsss/zdwz/200807/t20080724_ 51763.html (last accessed on 24 October 2011).

$262 \mathrm{Xu}$ Yang [徐阳] 'Harmfulness of and Safeguard Against Power Abuse in Criminal Reconciliation [刑事和解中权力过度推进之危害及其防范]' (2009) 6 Legal Review [法学评论] 134.

263 Ibid.

264 Chen Weidong [陈卫东] 'Several Opinions on Criminal Reconciliation [关于刑事和解的几点看法]' (2009) 3 Chinese Laws [中国法律] 12.

265 Supra note 194, 303. 
Criminal reconciliation leads to particular needs of checks (on the officials' power) and the passive role (of the officials' role in this programme). The initiative in criminal reconciliation programmes should be on the parties' side. Even so, public power has been so strong in criminal reconciliation, now that officials can decide to initiate this programme entirely by themselves. Therefore, checks from inside and outside of this system are of great significance to curb the abuse of power and prevent judicial corruption.

Yet such a supervision system to curb public power in criminal reconciliation processes is not addressed in the 2012 CPL. Furthermore, it would be difficult to create an effective supervision system in the Chinese criminal justice system taking into account the problems and 'malfunctioning' of the current supervision system stipulated in the Criminal Procedure Law. Indeed, the very idea of 'supervision' in the Chinese context may be in itself problematic. These points are discussed in detail in Chapter 6.

As described above, although neither the local regulations or guidelines nor the 2012 CPL allows it, the use of criminal reconciliation in practice has been extended from suspected minor crimes to felonies and capital cases. This 'development' has triggered much debate and concern in Chinese academia. Scholars who are generally supportive of the practice may still be critical of what they see as its excessive uses.

The primary justification for the use of criminal reconciliation in capital cases is concerned with its intended function of implementing the Party's policy of 'killing less, killing with restraint' (shao sha, shen sha) and an effective way to restrict the use of the death penalty in China. Nevertheless, it has been heavily criticized by the scholars. Scholars such as Liang Genlin and Sun Wanhuai argue that 'the control of [uses of the] death penalty should not rely on criminal reconciliation which almost upgrades compensation as the unique element in judges' consideration in capital sentence.' 266 That is to say, if the payment of compensation by the victim can lawfully become a major consideration affecting the judge's sentence in capital cases, this might reinforce the impression that life could also be 'bought' with money, and if you were too poor to afford compensation, you would have to face the death penalty.

Is criminal reconciliation in capital cases and suspected serious crimes legitimate, then, if it does not focus on compensation? Liang Genlin sees this 'extension' as an 'erosion of the State's power to impose criminal

266 Liang Genlin [梁根林] 'Ten Falsification in Using Criminal Reconciliation in Death Penalty Cases [死刑案件被刑事和解的十大证伪]' (2010) 4 Legal Science [法学] 18; supra note 184. 
punishment,' because it has 'privatized the Criminal Law to an extreme,' and is actually an 'excuse for the state to evade its responsibility in addressing the damage caused by crime.' ${ }^{267}$ According to Liang, compensating the victim's loss caused by the crime should not only be the offender's responsibility; rather, the state should also take this responsibility through, for instance, establishing a national compensation system (to redress the loss of the victim). ${ }^{268}$ Moreover, Liang claims that the use of criminal reconciliation in capital cases has seriously violated the 'passive nature of the judiciary' (sifa de beidong xing) due to its great reliance on the officials' discretion, which is very likely to cause judicial corruption. ${ }^{269}$

Another scholar, Sun Wanhuai, also criticizes the use of criminal reconciliation in homicide cases on the grounds that the implementation of criminal reconciliation in these cases makes the victim's lost life part of a bargaining process, in which the victim's relatives, who bargain for compensation, have necessarily replaced the (direct) victim. ${ }^{270}$ This is, according to Sun, 'also a violation of [the principle of] criminal reconciliation in itself, since this process calls for communication and negotiation between the (direct) parties themselves in resolving the case.'271

The arguments advanced by Liang and Sun seem more persuasive and may not be limited to criminal reconciliation used in death penalty cases and suspected serious crimes. As already mentioned, Liang criticizes the official's discretion in this process as a violation of the 'passive nature of judiciary' that potentially harms the parties' rights. However, as mentioned earlier, this might also be a problem with the use of criminal reconciliation in suspected minor crimes and Liang offers no reason for why this problem exists only in major cases. Likewise, Sun's argument may have ignored the point that in traffic accident related crime cases (which belong to 'minor crime'), the (direct) victim may also be dead when criminal reconciliation is initiated so there is also no communication between the direct parties. In sum, Liang and Sun's criticisms sound as though criminal reconciliation is justifiable in suspected minor crimes (as provided in the local regulations or guidelines governing criminal reconciliation as pilot practices and the $2012 \mathrm{CPL}$ ). Yet they do

\footnotetext{
267 Ibid 15-17.

268 Ibid.

269 Ibid 19.

270 Supra note 184, 185.

271 Ibid.
} 
not explain why these concerns around criminal reconciliation in serious 'crimes' and death penalty cases can be set aside in minor criminal cases.

The support for the availability of criminal reconciliation otherwise (concerning its outcome of a lenient sentence), in particular by defendants and their lawyers, is understandable considering what a severe criminal justice system they are facing, ${ }^{272}$ and their support might be more the result of China's flawed criminal justice system. Yet given these abovementioned problems with criminal reconciliation, this goal, while understandable in individual cases, should not blind us to the potential injustice of this system. The injustice will be further elaborated in the ensuing chapters.

272 See, e.g. Dui Hua, a nonprofit humanitarian organization, estimates that there are around 4,000 executions of death penalty in China every year, 'Dui Hua Estimates 4,000 Executions in China, Welcomes Open Dialogue' https:// sna.etapestry.com/prod/viewEmailAsPage.do?databaseId=DuiHuaFoundation \& mailingId $=22213781 \&$ personaRef $=11073.0 .152691 \&$ jobRef $=2967.0 .31681565 \&$ memberId=789166155\&erRef $=11073.0 .152697 \&$ key $=$ e2eacaff $46787 \mathrm{bfeef}$ caa24c f35264c7 (last accessed on 1 March 2012). 